\title{
Current status and perspectives in translational biomarker research for PD-1/PD-L1 immune checkpoint blockade therapy
}

\author{
Weijie Ma ${ }^{1,3}$, Barbara M. Gilligan ${ }^{1}$, Jianda Yuan ${ }^{4,5}$ and Tianhong $\mathrm{Li}^{1,2^{*}}$
}

\begin{abstract}
Modulating immune inhibitory pathways has been a major recent breakthrough in cancer treatment. Checkpoint blockade antibodies targeting cytotoxic T-lymphocyte antigen 4 (CTLA-4) and programed cell-death protein 1 (PD-1) have demonstrated acceptable toxicity, promising clinical responses, durable disease control, and improved survival in some patients with advanced melanoma, non-small cell lung cancer (NSCLC), and other tumor types. About $20 \%$ of advanced NSCLC patients and $30 \%$ of advanced melanoma patients experience tumor responses from checkpoint blockade monotherapy, with better clinical responses seen with the combination of anti-PD-1 and anti-CTLA-4 antibodies. Given the power of these new therapies, it is important to understand the complex and dynamic nature of host immune responses and the regulation of additional molecules in the tumor microenvironment and normal organs in response to the checkpoint blockade therapies. In this era of precision oncology, there remains a largely unmet need to identify the patients who are most likely to benefit from immunotherapy, to optimize the monitoring assays for tumor-specific immune responses, to develop strategies to improve clinical efficacy, and to identify biomarkers so that immune-related adverse events can be avoided. At this time, PD-L1 immunohistochemistry $(\mathrm{IHC})$ staining using 22C3 antibody is the only FDA-approved companion diagnostic for patients with NSCLC-treated pembrolizumab, but more are expected to come to market. We here summarize the current knowledge, clinical efficacy, potential immune biomarkers, and associated assays for immune checkpoint blockade therapies in advanced solid tumors.
\end{abstract}

Keywords: Cancer immunotherapy, Cytotoxic T cells, Immune checkpoint blockade antibodies, PD-1, PD-L1, Immune-related adverse events, Biomarker, Precision oncology

\section{Background}

Since 2011, when the US Food and Drug Administration (FDA) approved ipilimumab for advanced melanoma, there has been an explosion of research interest and drug development for harnessing the immune system to fight against cancer. A general search for "immune therapy and cancer" in the clinicaltrials.gov database from

\footnotetext{
* Correspondence: thli@ucdavis.edu

'Division of Hematology \& Oncology, Department of Internal Medicine, University of California Davis Comprehensive Cancer Center, University of California, Davis, School of Medicine, 4501 X Street, Suite 3016, Sacramento, CA 95817, USA

2VA Northern California Health Care System, 10535 Hospital Way, Mather, CA 95655, USA

Full list of author information is available at the end of the article
}

2000 to 2010 shows 640 hits, while the same search on March 20, 2015 shows 7815 hits and December 23, 2015 shows 8941 hits. Active research in tumor immunology includes studies on adoptive $\mathrm{T}$ cell therapy and cancer vaccine, as well as clinical investigations into immune checkpoint blockade in monotherapy or combination therapies. First generation programed cell-death protein 1 (PD-1) blockade antibodies pembrolizumab and nivolumab obtained US FDA approval for advanced melanoma in 2014 and as second line therapy for non-small cell lung cancer (NSCLC) in 2015. We have seen a surge in the availability of immune checkpoint inhibitors for multiple cancer indications. Forecasts for 2013-2020 project that the market for immunotherapy will increase 
from approximately $\$ 1$ billion (US dollars) in 2013 to in excess of $\$ 7$ billion in 2020 (corresponding to $33 \%$ annual growth), across the seven major markets (USA, France, Germany, Italy, Spain, UK, and Japan) [1].

Unlike chemotherapy and molecularly targeted therapy, the checkpoint blockade immunotherapies result in durable clinical responses through the induction, activation, and expansion of tumor-specific cytotoxic $\mathrm{T}$ cells. Immune checkpoints play an essential role in maintaining self-tolerance and regulating the amplitude and duration of $\mathrm{T}$ cell responses. Two cytotoxic $\mathrm{T}$ cell immune checkpoint receptors (cytotoxic T-lymphocyte antigen 4 (CTLA-4) and PD-1) deliver inhibitory signals when bound to their respective ligands CD80/86 and programed cell-death ligand 1 (PD-L1)/2. Immunotherapies with checkpoint blockade antibodies that block CTLA-4 and PD-1 (or its ligand PD-L1) can restore and augment cytotoxic $\mathrm{T}$ cell responses against chemotherapy-refractory tumors, leading to durable responses and prolonged overall survival with tolerable toxicity. In the lymphatic tissues, anti-CTLA-4 antibody induces non-tumor-specific immune activation that is largely de novo induction of new responses. In tumor microenvironment, anti-PD-1/ PD-L1 antibody targets tumor-induced immune defects and repairing ongoing tumor immunity. In addition to these anti-CTLA-4 and anti-PD-1/PD-L1 antibodies, drugs targeting other immune checkpoints and/or costimulatory ligand-receptor inhibitors, such as lymphocyte activation gene 3 protein (LAG3) and T cell immunoglobulin and mucin-domain containing protein 3 (TIM-3), are currently being explored in many tumor types and will be discussed further in the "Principles of cancer immunotherapy" section.

Given the distinct and novel mechanisms of action of immunotherapy on effector immune cells, rather than tumor cells, there are emerging tumor response patterns that are not accurately assessed by Response Evaluation Criteria in Solid Tumors (RECIST). In 2009, a guideline for immune-related response criteria (irRC) was proposed for patients with advanced melanoma receiving ipilimumab [2]. This guideline has been used to evaluate the tumor response for ongoing immune checkpoint blockade therapies [3]. When assessed appropriately, approximately $20 \%$ of advanced NSCLC patients and $30-40 \%$ of advanced melanoma patients have objective tumor responses to $\mathrm{PD}-1$ blockade monotherapy. The combination of anti-PD-1 and anti-CTLA-4 antibodies increased the clinical response in advanced melanoma patients with a recent FDA approval [4]. In an attempt to increase the therapeutic, in checkpoint inhibitors, a companion diagnostic of PD-L1 immunohistochemistry (IHC) had been approved by the US FDA for selecting NSCLC patients treated with pembrolizumab. Interestingly, overall tumor responses, progression-free survival
(PFS) and overall survival (OS) were not consistently associated with PD-L1 expression in the patients receiving immune checkpoint inhibitors [5]. In this age of personalized medicine, finding and validating better immune biomarkers will enable us to select patients for cancer immunotherapies. It will also lead to a better understanding of the unique mechanisms of tumor response and resistance, to allow for the development of strategies to improve clinical efficacy, and to lead to better evaluation of response and monitoring assays for host immune function. Validating potential immune biomarkers will enable us to better select patients for cancer immunotherapies and to avoid immune-related adverse effects (irAEs). Many excellent review articles on cancer biomarkers and immune checkpoint inhibitors have been recently published [6-12]. In this review, we will focus on the current knowledge, clinical efficacy, available monitoring assays, and emerging novel technologies for identifying translational biomarkers for immune checkpoint blockade immunotherapies in advanced solid tumors.

\section{Principles of cancer immunotherapy}

Clinically apparent cancer can be thought of as a host's inability to eliminate transformed cells. Cancer immunotherapy refers to a diverse range of therapeutic approaches that harness the immune system to induce or restore the capacity of cytotoxic $\mathrm{T}$ cells, and other immune effector cells, and to recognize and eliminate cancer $[13,14]$. The field of cancer immunotherapy is undergoing a renaissance due to a greater understanding of the immune system and immunosurveillance. The immune system protects the host against tumor development but also promotes tumor growth by selecting for tumors of lower immunogenicity. This dual effect of the immune system on developing tumors creates a dynamic process termed cancer immunoediting, which is comprised of three phases: elimination, equilibrium, and escape [15]. Cancer cells are immunogenic through the generation of tumor-specific mutant antigens (TSMA, neoantigens) from somatic gene structural and/or epigenetic alterations [16]. During the elimination phase, immune effector cells (mainly $\mathrm{T}$ and natural killer (NK) lymphocytes) are activated by the inflammatory cytokines released by the growing tumor cells, macrophages, and stromal cells surrounding the tumor cells. The recruited tumor-infiltrating NK cells and macrophages produce interleukin 2 (IL-2), interleukin 12 (IL12), and interferon gamma (IFN $\gamma$ ), which kill tumor cells by cytotoxic mechanisms such as perforin, tumor necrosis factors (TNF)-related apoptosis-inducing ligands (TRAILs), and reactive oxygen species. Due to heterogeneity, tumor cells with a less immunogenic phenotype are able to escape this elimination phase (i.e., immunosurveillance) and expand during the equilibrium phase. 
The equilibrium phase may occur over a period of many years when, under Darwinian selection, new tumor cell variants emerge with mutations that further increase overall resistance to immune attack. During the escape phase, tumor cell variants breach the host's immune defenses conferring further resistance to immune detection [17].

Major mechanisms for escape include defective antigen presentation, tumor-induced inhibitory checkpoint pathways against effector $\mathrm{T}$ cell activity, infiltrating immunosuppressive immune cells including regulatory $\mathrm{T}$ cells (Treg) and myeloid-derived suppressor cells (MDSCs), and secretion of immunosuppressive cytokines (transforming growth factor beta (TGF- $\beta$ ), IL-6, vascular endothelial growth factor (VEGF)) $[7,18,19]$. Full activation of $\mathrm{T}$ and NK lymphocytes requires the coordinated participation of several surface receptors that meet their cognate ligands through structured transient cell-to-cell interactions known as immune synapses. Current PD-1/PD-L1 blockade therapies aim to boost the patient's effector T cells to specifically recognize and kill cancer cells. Table 1 summarizes the current list of major immune checkpoint inhibitors that have obtained FDA approval or are in the late phases of clinical development.

Immune checkpoints normally maintain self-tolerance, regulate the amplitude and duration of $\mathrm{T}$ cell responses, and prevent tissue damage. PD-1 and PD-L1 immune checkpoint blockade can restore the function of exhausted CD8 $\mathrm{T}$ cells in chronic viral infection, augmenting the existing tumor-specific immunity [20, 21]. Nevertheless, immune checkpoint inhibitors can override immune selftolerance, inducing a unique syndrome of autoimmune and autoinflammatory side effects (i.e., irAEs) [22]. Many of these irAEs resemble autoimmune diseases, such as autoinflammatory rheumatic disease, dermatologic disease, colitis, hepatitis, and endocrinopathies [23]. Therefore, almost all immunotherapy clinical trials have excluded individuals with preexisting autoimmune diseases, although a recent study demonstrates that the use of ipilimumab in cancer patients with autoimmune diseases is safe and effective [24]. However, a recent study showed the safety and efficacy of using anti-CTLA-4 antibody in patients with autoimmune disease [24]. Early detection and effective management of these irAEs are pivotal for a favorable clinical outcome. Theoretically, cytotoxic $\mathrm{T}$ cells against tumors and normal organs are different subclones that may not need to be activated in parallel. Further studies are warranted to specifically enhance tumor-specific cytotoxic $\mathrm{T}$ cell response and avoid unnecessary $\mathrm{T}$ cell response to normal tissues.

\section{Biology and mechanisms of PD-1 and PD-L1 molecules}

PD-1 (CD279) is expressed on many cell types including $\mathrm{T}$ cells, B cells, natural killer T cells, activated monocytes, and dendritic cells (DCs) in humans and mice [25]. In normal human lymphoid tissues, PD-1 is detected on germinal center-associated T cells [26]. PD-1 binds to the ligand PD-L1 (B7-H1, CD274) or PD-L2 (B7-DC, CD272). PD-L1 is typically expressed on the surface of tumor cells [27]. PD-L1 is also constitutively expressed on other cell types such as T and B cells, DCs, macrophages, mesenchymal stem cells, and bone marrow-derived mast cells [28]. Cell surface expression of PD-L1 can be upregulated on both tumor cells and other cell types after treatment with type I or type II interferons (IFNs) [29, 30], radiation [31-33], or chemotherapy [34-38]. Additionally, radiotherapy may induce direct tumor-cell killing and multiple immunomodulatory changes that can potentially influence the effectiveness of immunotherapy [31-33].

Engagement of PD-1 by its ligands, either PD-L1 or PDL2, induces a negative control signal resulting in the inhibition of $\mathrm{T}$ cell proliferation, cytokine production, and cytotoxic activity. PD-L1 can provide inhibitory signals to activated $\mathrm{T}$ cells through interactions with the surface receptor PD-1 or CD80 [25, 39]. These signals enable PD-L1-expressing tumor cells to evade immune detection by NK cells or T cells [40-42]. PD-L2 is encoded by PDCD1LG2, which is essential for T cell proliferation and IFN production. PD-L2 can stimulate PD-1 receptor signaling, resulting in " $\mathrm{T}$ cell exhaustion," a temporary inhibition of activation and proliferation that can be reversed by the removal of PD-1 signal [25].

Upregulation of PD-L1 on different tumor types inhibits the local antitumor $\mathrm{T}$ cell response. Figure 1 illustrates the expression and complex interaction of key molecules and co-stimulatory ligand receptors between tumor and immune cells in tumor microenvironment (TME), and the two potential mechanisms proposed to understand the biology and function of PD-L1 on tumor cells [43]. While constitutive oncogenic signals (such as protein kinase B (AKT), epidermal growth factor receptor (EGFR), KRAS pathways) upregulate PD-L1 expression on tumors as innate (tumor cell intrinsic) resistance (Fig. 1, left) [44-48], inflammatory signals generate cytokine-induced PD-L1 expression on either tumor cells or immune cells (myeloid suppressor cells, dendritic cell, macrophage, and lymphocytes) in the tumor microenvironment as adaptive resistance (Fig. 1, right) [49, 50]. Preclinical studies have demonstrated that blocking the PD-L1/PD-1 interaction increases the numbers of effector $\mathrm{T}$ cells, augments cytolytic activity of tumor-specific $\mathrm{T}$ cells, enhances the production of pro-inflammatory cytokines, brings effector $\mathrm{T}$ cells to the tumor sites, reduces numbers and suppression of Tregs at the tumor site, and downregulates the production of suppressive cytokines IL-10 [51-54]. Tumor-infiltrating T cells may also be functionally inert, due in part to the expression of PD-1 along with other inhibitory receptors $[27,55]$. The hallmarks of the PD-1/PD-L1 blockage effect include 
Table 1 Summary of clinical indication and ongoing evaluation of immune checkpoint inhibitors in major cancer types

\begin{tabular}{|c|c|c|c|c|}
\hline Target & Drug & Class & Company & $\begin{array}{l}\text { Clinical indication and ongoing evaluation (status; approval date; trial } \\
\text { identifier; country) }\end{array}$ \\
\hline \multirow[t]{2}{*}{ CTLA-4 } & $\begin{array}{l}\text { Ipilimumab (Yervoy } \\
\text { MDX-010, MDX-101) }\end{array}$ & $\begin{array}{l}\text { Human } \\
\text { lgG1/kappa }\end{array}$ & $\begin{array}{l}\text { Bristol-Myers } \\
\text { Squibb }\end{array}$ & $\begin{array}{l}\text { Metastatic melanoma (US FDA approved on March 25, 2011); metastatic } \\
\text { NSCLC (phase I has been completed; NCT01165216; Japan; phase II } \\
\text { reported, NCTO0527735, USA; phase III ongoing, NCT01285609; USA; } \\
\text { phase III ongoing NCT02279732; China) }\end{array}$ \\
\hline & $\begin{array}{l}\text { Tremelimumab } \\
\text { (ticilimumab, CP-675206) }\end{array}$ & $\begin{array}{l}\text { Human anti- } \\
\text { CTLA-4 IgG2 } \\
\text { mab }\end{array}$ & $\begin{array}{l}\text { Medlmmune/ } \\
\text { AstraZeneca }\end{array}$ & $\begin{array}{l}\text { Metastatic melanoma (phase I has been completed; NCT01103635; USA; } \\
\text { phase II has been completed, NCT00471887, USA); advanced hepatocellular } \\
\text { carcinoma (phase II has been completed; NCT01008358; Spain); Metastatic } \\
\text { NSCLC (phase Ib has been reported, NCT02000947, USA; phase II has been } \\
\text { reported, NCT02179671, USA; first line, phase III MYSTIC ongoing; } \\
\text { NCT02453282; USA) }\end{array}$ \\
\hline PD-1 & $\begin{array}{l}\text { Nivolumab (Opdivo } \\
\text { ONO-4538, MDX-1106, } \\
\text { BMS-936558) }\end{array}$ & $\begin{array}{l}\text { Human } \\
\text { lgG4/kappa }\end{array}$ & $\begin{array}{l}\text { Bristol-Myers } \\
\text { Squibb; Ono } \\
\text { Pharmaceuticals }\end{array}$ & $\begin{array}{l}\text { Metastatic melanoma (Japan approval on July 4, 2014; US FDA accelerated } \\
\text { approval on December 22, 2014; US FDA approval of nivolumab in } \\
\text { combination with ipilimumab for BRAF V600 wild-type tumor on } \\
\text { September 30, 2015); Squamous NSCLC (US FDA approval on March 4, } \\
\text { 2015; European Commission on July 20, 2015); expands to non-squamous } \\
\text { NSCLC (US FDA approval on October 9, 2015); advanced (metastatic) renal } \\
\text { cell carcinoma (US FDA approval on November 23, 2015); classical Hodgkin } \\
\text { lymphoma that has relapsed or progressed after autologous hematopoietic } \\
\text { stem cell transplantation and post-transplantation brentuximab vedotin } \\
\text { (US FDA approval on May 17, 2016) }\end{array}$ \\
\hline
\end{tabular}

Pembrolizumab (Keytruda®, Humanized Merck \& Co. lambrolizumab, MK-3475)

Pidilizumab
(CT-011)

AMP-514 (MEDI0680)

AUNP-12

PD-L1 BMS936559

(MDX-1105)

Atezolizumab

(Tecentriq ${ }^{\text {MM }}$, MPDL3280A, RG7446)

Durvalumab

(MEDI4736)
$\operatorname{lgG} 4$

$\begin{array}{ll}\begin{array}{l}\text { Humanized } \\ \lg \mathrm{G} 1\end{array} & \text { CureTech Ltd } \\ \begin{array}{l}\text { Humanized } \\ \text { IgG4 }\end{array} & \text { Medlmmune } \\ \begin{array}{l}\text { Peptide } \\ \text { antagonist }\end{array} & \begin{array}{l}\text { Aurigene, Pierre } \\ \text { Fabre }\end{array} \\ \text { Human IgG4 } & \begin{array}{l}\text { Bristol-Myers } \\ \text { Squibb }\end{array} \\ \text { Human IgG1 } & \begin{array}{l}\text { Roche \& } \\ \text { Genentech }\end{array}\end{array}$

Humanized AstraZeneca $\lg G 1$
Metastatic melanoma (USA accelerated approval on September 4, 2014 for patients with disease progression after ipilimumab and, if BRAF V600 mutation positive, a BRAF inhibitor; US FDA expanded to initial treatment on December 18, 2015); metastatic NSCLC whose tumors express PD-L1 as determined by an FDA-approved test and who have disease progression on or after platinum-containing chemotherapy (US FDA approval on October 2, 2015)

Diffuse large-B cell lymphoma (phase II has been completed; NCT00532259; USA); metastatic melanoma (phase II has been completed; NCT01435369; USA)

Advanced malignancies (phase II is currently recruiting participants; NCT02013804; USA)

Cancer (preclinical phase, Aurigene granted Pierre Fabre worldwide rights to develop AUNP12 for cancer indications; announced on February 11, 2014; India)

Advanced or recurrent solid tumors (phase II has been completed; NCT00729664; USA)

Metastatic bladder cancer (phase III, US FDA granted breakthrough therapy designation on May 31, 2014; priority review on March 14, 2016; accelerated approval on May 18, 2016); metastatic NSCLC (phase III, US FDA grants breakthrough therapy designation on February 1, 2015)

Glioblastoma (phase II is currently recruiting participants; NCT02336165; USA); metastatic squamous cell carcinoma of the head and neck (phase II is currently recruiting participants; NCT02207530; USA); advanced or metastatic NSCLC (phase III is currently recruiting participants; NCT02352948; Global study); advanced colorectal cancer (phase II is currently recruiting participants; NCT02227667; USA); metastatic NSCLC (first line phase III MYSTIC is current recruiting participants; NCT02453282; USA; first line phase III ARCTIC is current recruiting participants; NCT02352948; Global); metastatic bladder cancer (US FDA granted breakthrough therapy designation for PD-L1-positive tumors in patients who progressed during or after one standard platinum-based regimen on February 17, 2016)

$\begin{array}{lll}\text { Avelumab } & \text { Fully } & \text { Merck KGaA, EMD } \\ \text { (MSB0010718C) } & \text { humanized } & \text { Serono, Pfizer } \\ & \text { lgG1 } & \end{array}$

Advanced solid tumors (phase I with consecutive parallel group expansion; currently recruiting participants in multiple tumor types and settings; NCT01772004; USA); metastatic NSCLC (phase III is currently recruiting participants after failure of a platinum-based doublet; NCT02395172; and first line versus platinum doublet; NCT02576574; USA) 


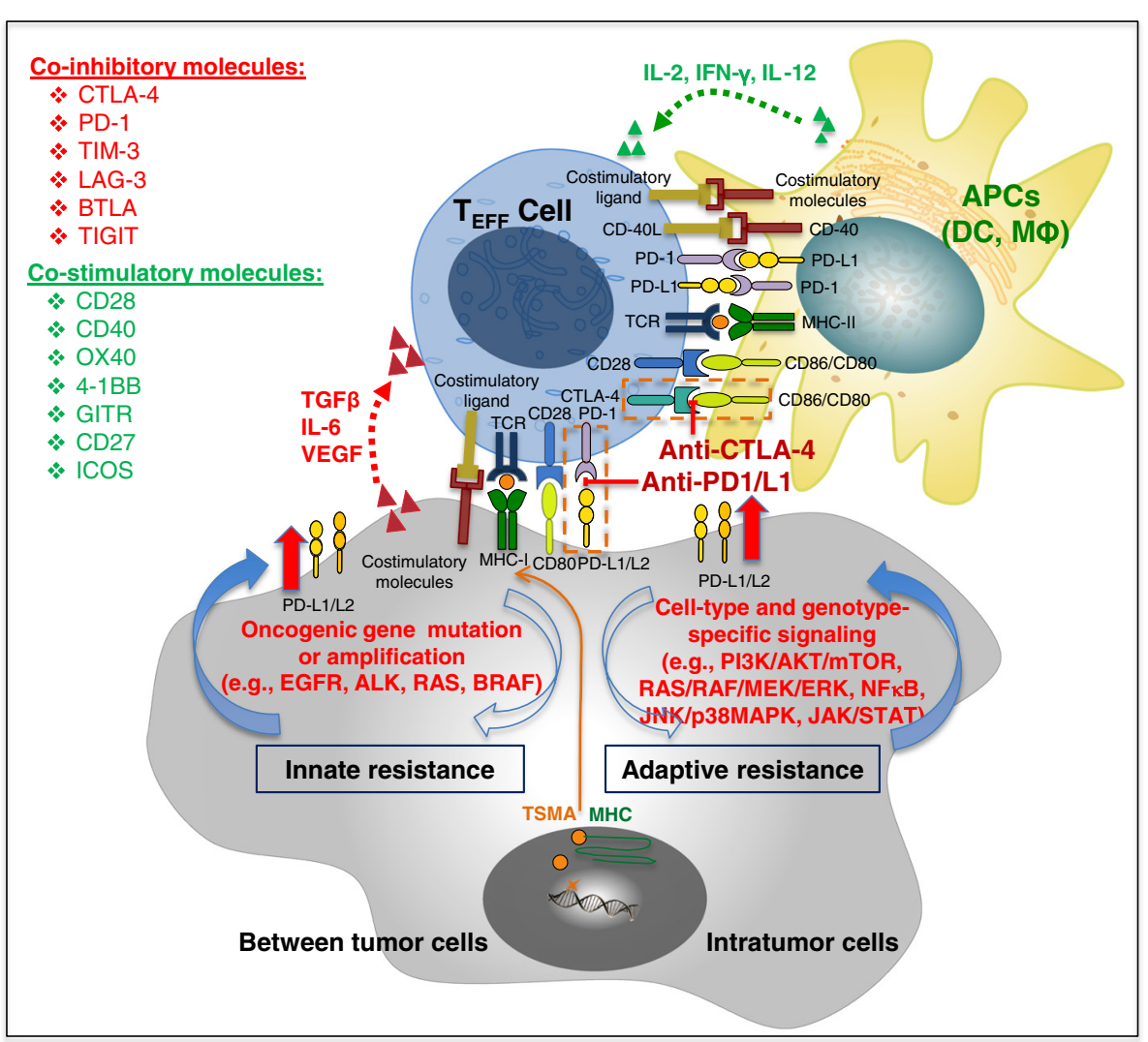

Fig. 1 Schema interaction between tumor and immune cells. Full activation of T-lymphocytes requires the coordinated participation of several surface receptors on effector T cells and antigen-presenting cells (APCs) or tumor cells. The main route of T cell stimulation is driven by antigens recognized in the form of short polypeptides associated with MHC antigen-presenting molecules. However, the functional outcome of T cell stimulation towards clonal expansion and effector function acquisition is contingent on the contact of additional surface receptor-ligand pairs and on the actions of cytokines in the tumor microenvironment. While some of those interactions are inhibitory (in red), others are activating and are collectively termed co-stimulatory (in green) receptors. Communication between T cells and APCs is bidirectional. In some cases, this occurs when ligands themselves signal to the APC. In other cases, activated T cells upregulate ligands, such as CD40L, that engage cognate receptors on APCs. Tumor cells can upregulate PD-L1 expression via either the constitutionally activated oncogenic signaling (left, innate/intrinsic immune resistance) or the immune modulator-induced signaling pathways (right, adaptive immune resistance). Abbreviations: APC antigen-presenting cells, DC dendritic cell, IL-2R IL-2 receptor, MDSCs myeloid-derived suppressor cells, Teff effector T cell, Treg regulatory T cells, IDO indoleamin 2,3-dioxygenase, TIM-3 T cell immunoglobulin domain and mucin domain, LAG lymphocyte-activation gene, BTLA B-and T-lymphocyte attenuator, HVEM herpes virus entry mediator, TIGIT T cell immunoreceptor with Ig and ITIM domains, GITR glucocorticoid-induced tumor necrosis factor receptor, ICOS inducible costimulators, CEACAM carcinoembryonic antigen-related cell adhesion molecule, TSMA tumor-specific mutant antigens, JNK, c-Jun N-terminal kinase, MEKJERK, mitogen/extracellular signal regulated kinase, PI3K, phosphatidylinositol 3-kinase, STAT, signal transducer and activator of transcription, NFKB, nuclear factor kappa-light-chain-enhancer of activated B cells

immune modulation at tumor site, direct targeting of tumor-induced immune defects, and repairing ongoing tumor immunity. PD-1 deletion in mice can lead to autoimmunity, most notably when bred onto backgrounds of autoimmune-susceptible mouse strains [56, 57]. In multiple syngeneic mouse tumor models, blockade of PD-1 or its ligands promotes antitumor activity $[58,59]$; anti-PD-1 activity in vivo can be enhanced by combination with antibodies to other $\mathrm{T}$ cell-negative regulators, such as CTLA-4 and LAG-3 [60-62]. A recent study suggests that PD-L1 is an independent prognostic marker in melanoma, defining a tumor subset with distinct genetic and morphophenotypic features [63].

\section{Clinical efficacy of PD-1/PD-L1 blockade therapies and PD-L1 expression}

Nivolumab and pembrolizumab are the first generation PD-1 immune checkpoint blockade antibodies. Nivolumab inhibits the interaction between PD-1 and its ligands, PD-L1, and PD-L2 with similar $\mathrm{IC}_{50}$ values $(2.52$ and $2.59 \mathrm{nmol} / \mathrm{L}$, respectively). Nivolumab enhances $\mathrm{T}$ cell reactivity in the presence of a $\mathrm{T}$ cell receptor stimulus at the low concentration $(\sim 1.5 \mathrm{ng} / \mathrm{mL})$ without nonspecific lymphocyte activation. Nivolumab also enhances the production of inflammatory cytokines in assays such as the human $\mathrm{T}$ cell/DC-mixed lymphocyte reaction (MLR) assays, and Staphylococcal enterotoxin B (SEB), 
and cytomegalovirus (CMV) recall response assays. In addition, nivolumab increases antigen-specific $\mathrm{CD} 8^{+} \mathrm{T}$ cell responses in patients with melanoma [64]. Nivolumab completely restored $\mathrm{CD} 4^{+}$T-responder cell proliferation and partially restored IFN $\gamma$ production. Nivolumab also overcomes Treg suppression of $\mathrm{CD} 8^{+} \mathrm{T}$ cells by increasing resistance to Treg suppression and also by directly limiting suppressive capacity of Treg [65]. This was demonstrated in monkeys when increased numbers of $\mathrm{CD} 8^{+} \mathrm{T}$-effector memory cells were detected in CMV-positive peripheral blood after repeated treatment at the highest dose of nivolumab for 3 months. Similarly, marked accumulation of $\mathrm{CD}^{+}$effector memory $\mathrm{T}$ cells in lymphoid organs and tissues of PD-1-deficient mice has been described [66].

Both nivolumab and pembrolizumab have shown significant survival benefit in some patients with advanced melanoma, NSCLC, and renal cell carcinomas in early clinical trials (Table 1). These agents were generally well tolerated, even in elderly patients with prolonged dosing. Lower tumor response rates have been observed in never smokers and patients with EGFR mutations or ALK rearrangements when compared to heavy smokers. Table 2 summarizes this clinical efficacy data from four of the most studied PD-1 and PD-L1 inhibitors at various stages of clinical development. As only subsets of patients are benefiting from the PD-1/PD-L1 immune checkpoint blockade therapies, it is important to try to select for this population so that patients less likely to improve with therapy can be spared toxicities. An additional challenge is that response criteria used for standard therapy may not be applicable for immunotherapy. Unlike standard therapeutics in which tumor response is measured by a variety of radiographic and laboratory tests every 6-8 weeks, delayed tumor responses due to the time required for activation and function of effector $\mathrm{T}$ cells are frequently observed in cancer patients treated with immune checkpoint blockade therapies. In some patients, tumor regression persisted after discontinuation of PD-1 blockade therapy [67]. Evaluating responses appropriately and identifying patients who are most likely to respond are important aspects of immunotherapy that continue to be developed.

\section{Biomarkers for PD-1/PD-L1 blockade therapies}

Translational biomarker research is critical for the future of drug development for clinical immune checkpoint blockade therapy. Only one PD-L1 IHC has been approved as a companion diagnostic by the US FDA for patients with advanced NSCLC for pembrolizumab [68]. The challenges in developing immuno-oncology biomarkers for clinical use have been recognized by regulatory agencies and professional societies such as the Society for Immunotherapy of Cancer (SITC) [69]. Over the past several years, the SITC Immune Biomarkers Task force has provided the roadmap and regular updates on immune biomarker development
[70-72]. Immunological changes in peripheral blood and tumor could potentially reflect tumor response in patients and serve as immune biomarkers. The immune monitoring assays had been developed to evaluate these potential biomarkers before and after immune checkpoint blockade therapies and investigate their correlation with clinical outcome (Fig. 2). These biomarkers could be classified into two groups: tumor-derived immune biomarkers and immune cell-derived biomarkers as discussed in the following sections. Table 3 summarizes currently available quantitative biomarker assays for immune checkpoint inhibitors.

\section{Current immune monitoring assays IHC staining}

PD-L1 is the best studied immuno-oncology biomarker to date. Currently, PD-L1 IHC using 22C3 antibody is the only FDA-approved companion diagnostic for selecting NSCLC patients for pembrolizumab [68]. Table 4 summarizes the IHC assays used for PD-L1 expression using baseline archival tumor specimens in these clinical studies [73]. There are many variables in these IHC assays. First, the time between sample collection and treatment with a PD-1 or PDL1 inhibitor is not controlled. Second, tumor cells, immune cells, as well as stroma cells can express PD-L1 with considerably heterogeneity within the tumor microenvironment. Third, PD-L1 expression is induced by IFN $\gamma$ during disease progression and treatment. Fourth, different PD-L1 antibodies were used for different immune checkpoint blockade clinical studies. Currently, there is no validated antibody for IHC staining for this class of immune checkpoint inhibitors-each sponsor uses different antibodies. Antibodies staining tumor cells or stroma cells may have different PD-L1 epitopes (Table 4). An additional challenge is that none of the commercial PD-L1 IHC test has been validated in terms of clinical outcomes. Head-to-head comparisons among three different commercially available PDL1 assays (Dako 22C3, Dako 28-8, and Ventana SP263 as the reference) using 500 formalin-fixed, paraffin-embedded archival samples of NSCLC tissue obtained from commercial sources found 91 to $95 \%$ correlation, which is comparable to typical within assay agreement for IHC across the dynamic range at multiple cutoffs [74]. A recent meta-analysis demonstrates that PD-L1 expression is significantly associated with clinical response to anti-PD-1/ PD-L1 antibodies in patients with malignant melanoma (MM) or non-squamous NSCLC. However, a proportion of PD-L1-negative patients also benefits from anti-PD-1 therapy in MM and squamous-NSCLC. Thus, expression of PD-L1 in tumor tissues cannot be used as a predictive biomarker of eligibility for treatment with anti-PD-1/PDL1 antibodies. It may represent a correlation marker for non-squamous NSCLC and melanoma [75].

The presence of tumor-infiltrating lymphocytes (TILs) at tumor microenvironment has been associated with an 
Table 2 Summary of reported clinical efficacy of PD-1/PD-L1 inhibitors

\begin{tabular}{|c|c|c|c|c|c|c|c|c|c|c|}
\hline Agent & $\begin{array}{l}\text { Clinical trials } \\
\text { identifier }\end{array}$ & $\begin{array}{l}\text { Phase of } \\
\text { clinical trial }\end{array}$ & $\begin{array}{l}\text { Sample size } \\
\text { (no. Pt) }\end{array}$ & Patient population & Biomarker & Regimen & $\begin{array}{l}\text { Tumor } \\
\text { responses } \\
\text { (ORR) }\end{array}$ & $\begin{array}{l}\text { Median } \\
\text { PFS } \\
\text { (months) }\end{array}$ & $\begin{array}{l}\text { OS } \\
\text { (months; } \\
\text { median } \\
\text { unless } \\
\text { otherwise } \\
\text { specified) }\end{array}$ & $\begin{array}{l}\text { Reference: } \\
\text { author } \\
\text { (year) }\end{array}$ \\
\hline \multirow[t]{12}{*}{ Nivolumab } & \multirow[t]{2}{*}{$\begin{array}{l}\text { NCT01642004 } \\
\text { (CheckMate 017) }\end{array}$} & \multirow[t]{2}{*}{ Phase III } & \multirow{2}{*}{$\begin{array}{l}272 \text { all: } 135 \\
\text { nivolumab, } 137 \\
\text { docetaxel }\end{array}$} & \multirow{2}{*}{$\begin{array}{l}\text { Advanced squamous } \\
\text { NSCLC with disease } \\
\text { progression during } \\
\text { or after first-line } \\
\text { chemotherapy }\end{array}$} & \multirow{2}{*}{$\begin{array}{l}\text { PD-L1- } \\
\text { positive } \\
\text { tumor cells }\end{array}$} & $\begin{array}{l}\text { Nivolumab } 3 \text { mg/kg IV } \\
\text { every } 2 \text { weeks }\end{array}$ & $20 \%$ & 3.5 & 9.2 & \multirow{2}{*}{$\begin{array}{l}\text { Brahmer } \\
J(2015) \\
{[125]}\end{array}$} \\
\hline & & & & & & $\begin{array}{l}\text { Docetaxel } 75 \mathrm{mg} / \mathrm{m}^{2} \mathrm{IV} \\
\text { every } 3 \text { weeks }\end{array}$ & $9 \%$ & 2.8 & 6 & \\
\hline & \multirow[t]{2}{*}{$\begin{array}{l}\text { NCT01673867 } \\
\text { (CheckMate 057) }\end{array}$} & \multirow[t]{2}{*}{ Phase III } & \multirow{2}{*}{$\begin{array}{l}582 \text { all: } 292 \\
\text { nivolumab, } 290 \\
\text { Docetaxel }\end{array}$} & \multirow{2}{*}{$\begin{array}{l}\text { Advanced non- } \\
\text { squamous NSCLC } \\
\text { after platinum- } \\
\text { based doublet } \\
\text { chemotherapy }\end{array}$} & \multirow{2}{*}{$\begin{array}{l}\text { PD-L1- } \\
\text { positive } \\
\text { tumor cells }\end{array}$} & $\begin{array}{l}\text { Nivolumab } 3 \text { mg/kg IV } \\
\text { every } 2 \text { weeks }\end{array}$ & $19 \%$ & 2.3 & 12.2 & \multirow{2}{*}{$\begin{array}{l}\text { Borghaei } \\
\text { H (2015) } \\
{[126]}\end{array}$} \\
\hline & & & & & & $\begin{array}{l}\text { Docetaxel } 75 \mathrm{mg} / \mathrm{m} 2 \mathrm{IV} \\
\text { every } 3 \text { weeks }\end{array}$ & $12 \%$ & 4.2 & 9.4 & \\
\hline & \multirow[t]{2}{*}{$\begin{array}{l}\text { NCT01668784 } \\
\text { (CheckMate 025) }\end{array}$} & \multirow[t]{2}{*}{ Phase III } & \multirow{2}{*}{$\begin{array}{l}821 \text { all: } 406 \\
\text { nivolumab, } 397 \\
\text { Everolimus }\end{array}$} & \multirow{2}{*}{$\begin{array}{l}\text { Advanced clear-cell } \\
\text { renal-cell carcinoma } \\
\text { with one or two } \\
\text { regimens of anti- } \\
\text { angiogenic therapy }\end{array}$} & \multirow{2}{*}{$\begin{array}{l}\text { PD-L1- } \\
\text { positive } \\
\text { tumor cells }\end{array}$} & $\begin{array}{l}\text { Nivolumab } 3 \text { mg/kg IV } \\
\text { every } 2 \text { weeks }\end{array}$ & $25 \%$ & 4.6 & 25 & \multirow{2}{*}{$\begin{array}{l}\text { Motzer } \\
\text { RJ (2015) } \\
{[127]}\end{array}$} \\
\hline & & & & & & $\begin{array}{l}\text { Everolimus } 10 \text { mg orally } \\
\text { daily }\end{array}$ & $5 \%$ & 4.4 & 19.6 & \\
\hline & \multirow[t]{2}{*}{$\begin{array}{l}\text { NCT01721746 } \\
\text { (CheckMate 037) }\end{array}$} & \multirow[t]{2}{*}{ Phase III } & \multirow{2}{*}{$\begin{array}{l}631 \text { all: } 272 \\
\text { nivolumab, } 133 \\
\text { investigators } \\
\text { choice of } \\
\text { chemo }\end{array}$} & \multirow{2}{*}{$\begin{array}{l}\text { Unresectable or } \\
\text { metastatic melanoma } \\
\text { after ipilimumab or } \\
\text { ipilimumab and BRAF } \\
\text { inhibitor if BRAF } \\
\text { positive }\end{array}$} & \multirow{2}{*}{$\begin{array}{l}\text { PD-L1- } \\
\text { positive } \\
\text { tumor cells }\end{array}$} & $\begin{array}{l}\text { Nivolumab } 3 \mathrm{mg} / \mathrm{kg} \text { IV } \\
\text { every } 2 \text { weeks }\end{array}$ & $32 \%$ & 4.7 & NA & \multirow{2}{*}{$\begin{array}{l}\text { Weber } \\
\text { JS (2015) } \\
{[128]}\end{array}$} \\
\hline & & & & & & $\begin{array}{l}\text { Chemo: either dacarbazine } \\
1000 \mathrm{mg} / \mathrm{m} 2 \text { IV every } 3 \\
\text { weeks or carboplatin } \\
\text { AUC }=6 \text { plus paclitaxel } \\
185 \mathrm{mg} / \mathrm{m} 2 \text { IV every } \\
3 \text { weeks }\end{array}$ & $11 \%$ & 4.2 & NA & \\
\hline & \multirow[t]{2}{*}{$\begin{array}{l}\text { NCT01927419 } \\
\text { (CheckMate 069) }\end{array}$} & \multirow[t]{2}{*}{ Phase III } & \multirow[t]{2}{*}{$\begin{array}{l}142 \text { all: } 95 \\
\text { nivolumab + } \\
\text { ipilimumab, } 47 \\
\text { ipilimumab }\end{array}$} & \multirow[t]{2}{*}{$\begin{array}{l}\text { Unresectable or } \\
\text { metastatic melanoma } \\
\text { treatment naïve with } \\
\text { measurable disease }\end{array}$} & \multirow[t]{2}{*}{$\begin{array}{l}\text { Tissue } \\
\text { available } \\
\text { for PD-L1 } \\
\text { biomarker } \\
\text { analysis }\end{array}$} & $\begin{array}{l}\text { Nivolumab } 1 \mathrm{mg} / \mathrm{kg} \text { IV } \\
\text { every } 3 \text { weeks } \times 4 \text { doses } \\
\text { plus ipilimumab } 3 \mathrm{mg} / \mathrm{kg} \\
\text { IV every } 3 \text { weeks } \times 4 \\
\text { doses, then maintenance } \\
\text { nivolumab } 3 \mathrm{mg} / \mathrm{kg} \text { IV } \\
\text { every } 2 \text { weeks }\end{array}$ & $\begin{array}{l}\text { BRAF wild } \\
\text { type: } 61 \% \text {; } \\
\text { BRAF } \\
\text { mutation: } \\
52 \%\end{array}$ & $\begin{array}{l}\text { BRAF wild } \\
\text { type: NR; } \\
\text { BRAF } \\
\text { mutation: } \\
8.5\end{array}$ & NA & \multirow[t]{2}{*}{$\begin{array}{l}\text { Postow } \\
\text { MA } \\
\text { (2015) [4] }\end{array}$} \\
\hline & & & & & & $\begin{array}{l}\text { Same dose schedule with } \\
\text { nivolumab placebo in both } \\
\text { the combination and } \\
\text { maintenance phase }\end{array}$ & $\begin{array}{l}\text { BRAF wild } \\
\text { type: } 11 \% \text {; } \\
\text { BRAF } \\
\text { mutation: } \\
22 \%\end{array}$ & $\begin{array}{l}\text { BRAF wild } \\
\text { type: } 4.4 ; \\
\text { BRAF } \\
\text { mutation: } \\
2.7\end{array}$ & NA & \\
\hline & \multirow[t]{2}{*}{$\begin{array}{l}\text { NCT01721772 } \\
\text { (CheckMate 066) }\end{array}$} & \multirow[t]{2}{*}{ Phase III } & \multirow[t]{2}{*}{$\begin{array}{l}418 \text { all: } 210 \\
\text { nivolumab, } 208 \\
\text { dacarbazine }\end{array}$} & \multirow[t]{2}{*}{$\begin{array}{l}\text { Untreated metastatic } \\
\text { melanoma without } \\
\text { BRAF mutation }\end{array}$} & \multirow{2}{*}{$\begin{array}{l}\text { Tissue } \\
\text { available } \\
\text { for PD-L1 } \\
\text { biomarker } \\
\text { analysis }\end{array}$} & $\begin{array}{l}\text { Nivolumab } 3 \mathrm{mg} / \mathrm{kg} \text { IV } \\
\text { every } 2 \text { weeks plus } \\
\text { placebo every } 3 \text { weeks }\end{array}$ & $40 \%$ & 5.1 & $\begin{array}{l}\text { 1-year } \\
\text { OS: } \\
72.9 \%\end{array}$ & \multirow[t]{2}{*}{$\begin{array}{l}\text { Robert } \\
\text { C (2015) } \\
{[129]}\end{array}$} \\
\hline & & & & & & $\begin{array}{l}\text { Dacarbazine } 1000 \\
\mathrm{mg} / \mathrm{m} 2 \mathrm{IV} \text { every } 3\end{array}$ & $13.9 \%$ & 2.2 & $\begin{array}{l}\text { 1-year } \\
\text { OS: } \\
42.1 \%\end{array}$ & \\
\hline
\end{tabular}


Table 2 Summary of reported clinical efficacy of PD-1/PD-L1 inhibitors (Continued)

\begin{tabular}{|c|c|c|c|c|c|c|c|c|c|c|}
\hline & & & & & & $\begin{array}{l}\text { weeks plus placebo } \\
\text { every } 2 \text { weeks }\end{array}$ & & & & \\
\hline & \multirow[t]{3}{*}{$\begin{array}{l}\text { NCT01844505 } \\
\text { (CheckMate 067) }\end{array}$} & \multirow[t]{3}{*}{ Phase III } & \multirow{3}{*}{$\begin{array}{l}945 \text { all: } 316 \\
\text { nivolumab, } 314 \\
\text { combination, } \\
315 \text { ipilimumab }\end{array}$} & \multirow[t]{3}{*}{$\begin{array}{l}\text { Untreated, } \\
\text { unresectable stage } \\
\text { III or IV melanoma }\end{array}$} & \multirow{3}{*}{$\begin{array}{l}\text { Tissue } \\
\text { available } \\
\text { for PD-L1 } \\
\text { biomarker } \\
\text { analysis }\end{array}$} & $\begin{array}{l}\text { Nivolumab } 3 \mathrm{mg} / \mathrm{kg} \\
\text { IV every } 2 \text { weeks (plus } \\
\text { ipilimumab placebo) }\end{array}$ & $43.7 \%$ & 6.9 & NA & \multirow[t]{3}{*}{$\begin{array}{l}\text { Larkin } \\
\text { J (2015) } \\
{[130]}\end{array}$} \\
\hline & & & & & & $\begin{array}{l}\text { Nivolumab } 1 \mathrm{mg} / \mathrm{kg} \\
\text { IV every } 3 \text { weeks plus } \\
\text { ipilimumab } 3 \mathrm{mg} / \mathrm{kg} \\
\text { IV every } 3 \text { weeks } \times 4 \\
\text { doses; then maintenance } \\
\text { nivolumab } 3 \mathrm{mg} / \mathrm{kg} \\
\text { IV every } 2 \text { weeks }\end{array}$ & $58 \%$ & 11.5 & & \\
\hline & & & & & & $\begin{array}{l}\text { Ipilimumab } 3 \text { mg/kg IV } \\
\text { every } 3 \text { weeks (plus } \\
\text { nivolumab placebo) }\end{array}$ & $19 \%$ & 2.9 & & \\
\hline & $\begin{array}{l}\text { NCT01721759 } \\
\text { (CheckMate 063) }\end{array}$ & $\begin{array}{l}\text { Phase II } \\
\text { single arm } \\
\text { trial }\end{array}$ & 117 & Advanced NSCLC & $\begin{array}{l}\text { PD-L1- } \\
\text { positive } \\
\text { tumor cells }\end{array}$ & $\begin{array}{l}\text { Nivolumab } 3 \mathrm{mg} / \mathrm{kg} \\
\text { every } 2 \text { weeks until } \\
\text { progression or } \\
\text { unacceptable } \\
\text { toxic effects }\end{array}$ & $14.5 \%$ & 1.9 & 8.2 & $\begin{array}{l}\text { Rizvi } \\
\text { NA (2015) } \\
\text { [131] }\end{array}$ \\
\hline & NCT00730639 & $\begin{array}{l}\text { Phase I } \\
\text { with } \\
\text { expansion } \\
\text { cohorts }\end{array}$ & 107 & $\begin{array}{l}\text { Advanced } \\
\text { melanoma }\end{array}$ & Unselected & $\begin{array}{l}\text { Nivolumab at } 1,3 \text {, or } \\
10 \mathrm{mg} / \mathrm{kg} \text { every } 2 \\
\text { weeks for up to } \\
96 \text { weeks }\end{array}$ & $31 \%$ & 3.7 & 16.8 & $\begin{array}{l}\text { Topalian } \\
\text { SL (2014) } \\
{[67]}\end{array}$ \\
\hline & & $\begin{array}{l}\text { Phase I } \\
\text { with } \\
\text { expansion } \\
\text { cohorts }\end{array}$ & 34 & $\begin{array}{l}\text { Previously treated } \\
\text { advanced RCC }\end{array}$ & Unselected & $\begin{array}{l}\text { Nivolumab at } 1,3 \text {, or } \\
10 \mathrm{mg} / \mathrm{kg} \text { every } 2 \\
\text { weeks for up to } \\
96 \text { weeks }\end{array}$ & $29 \%$ & 7.3 & 22.4 & $\begin{array}{l}\text { McDermott } \\
\text { DF (2015) } \\
\text { [132] }\end{array}$ \\
\hline & & $\begin{array}{l}\text { Phase II } \\
\text { with } \\
\text { expansion } \\
\text { cohorts }\end{array}$ & 129 & $\begin{array}{l}\text { Heavily pretreated } \\
\text { advanced NSCLC }\end{array}$ & Unselected & $\begin{array}{l}\text { Nivolumab at } 1,3 \text {, or } \\
10 \mathrm{mg} / \mathrm{kg} \text { every } 2 \\
\text { weeks for up to } \\
96 \text { weeks }\end{array}$ & $17 \%$ & 2.6 & 9.9 & $\begin{array}{l}\text { Gettinger } \\
\text { SN (2015) } \\
{[133]}\end{array}$ \\
\hline \multirow[t]{6}{*}{ Pembrolizumab } & \multirow[t]{3}{*}{$\begin{array}{l}\text { NCT01866319 } \\
\text { (KEYNOTE-006) }\end{array}$} & \multirow[t]{3}{*}{ Phase III } & \multirow{3}{*}{$\begin{array}{l}834 \text { all: } 279 \\
\text { pembrolizumab, } \\
277 \text { pembrolizumab, } \\
278 \text { ipilimumab }\end{array}$} & \multirow{3}{*}{$\begin{array}{l}\text { Unresectable stage } \\
\text { III or IV melanoma }\end{array}$} & \multirow{3}{*}{$\begin{array}{l}\text { PD-L1- } \\
\text { positive } \\
\text { tumor cells }\end{array}$} & $\begin{array}{l}\text { Pembrolizumab } 3 \\
\mathrm{mg} / \mathrm{kg} \text { IV every } 2 \text { weeks }\end{array}$ & $33.7 \%$ & 5.5 & \multirow[t]{3}{*}{ NA } & \multirow{3}{*}{$\begin{array}{l}\text { Robert } \\
\text { C (2015) } \\
{[134]}\end{array}$} \\
\hline & & & & & & $\begin{array}{l}\text { Pembrolizumab } \\
3 \mathrm{mg} / \mathrm{kg} \mathrm{IV} \mathrm{every} \\
3 \text { weeks }\end{array}$ & $32.9 \%$ & 4.1 & & \\
\hline & & & & & & $\begin{array}{l}\text { Ipilimumab } 3 \text { mg/kg } \\
\text { IV every } 3 \text { weeks }\end{array}$ & $11.9 \%$ & 2.8 & & \\
\hline & \multirow[t]{3}{*}{$\begin{array}{l}\text { NCT01704287 } \\
\text { (KEYNOTE-002) }\end{array}$} & \multirow[t]{3}{*}{ Phase II } & \multirow{3}{*}{$\begin{array}{l}540 \text { all: } 180 \\
\text { pembrolizumab, } \\
181 \text { pembrolizumab, } \\
179 \text { chemotherapy }\end{array}$} & \multirow{3}{*}{$\begin{array}{l}\text { Ipilimumab-refractory } \\
\text { melanoma }\end{array}$} & \multirow{3}{*}{$\begin{array}{l}\text { Will be } \\
\text { reported } \\
\text { with the } \\
\text { final overall } \\
\text { survival } \\
\text { analysis }\end{array}$} & $\begin{array}{l}\text { Arm A } 2 \mathrm{mg} / \mathrm{kg} \\
(n=180)\end{array}$ & $21 \%$ & 5.4 & \multirow[t]{3}{*}{ NA } & \multirow{3}{*}{$\begin{array}{l}\text { Ribas } \\
\text { A (2015) } \\
{[135]}\end{array}$} \\
\hline & & & & & & $\begin{array}{l}\text { Arm B } 10 \mathrm{mg} / \mathrm{kg} \\
(n=181)\end{array}$ & $25 \%$ & 5.8 & & \\
\hline & & & & & & Chemotherapy & $4 \%$ & 3.6 & & \\
\hline
\end{tabular}


Table 2 Summary of reported clinical efficacy of PD-1/PD-L1 inhibitors (Continued)

\begin{tabular}{|c|c|c|c|c|c|c|c|c|c|c|}
\hline & \multirow[t]{3}{*}{$\begin{array}{l}\text { NCT012958297 } \\
\text { (KEYNOTE-001) }\end{array}$} & Phase I & 495 & Advanced NSCLC & $\begin{array}{l}\text { PD-L1- } \\
\text { positive } \\
\text { tumor cells }\end{array}$ & $\begin{array}{l}\text { Pembrolizumab } 2 \text { or } \\
10 \mathrm{mg} / \mathrm{kg} \text { IV every } \\
3 \text { weeks or } 10 \mathrm{mg} / \mathrm{kg} \\
\text { every } 2 \text { weeks over a } \\
30 \text {-min period }\end{array}$ & $19.4 \%$ & 3.7 & 12 & $\begin{array}{l}\text { Garon } \\
\text { EB (2015) } \\
{[5]}\end{array}$ \\
\hline & & Phase I & 655 & Melanoma & Unselected & $\begin{array}{l}\text { Pembrolizumab } 2 \mathrm{mg} / \mathrm{kg} \\
\text { every } 3 \text { weeks (Q3W), } 10 \\
\mathrm{mg} / \mathrm{kg} \mathrm{Q} 3 \mathrm{~W} \text {, or } 10 \mathrm{mg} / \mathrm{kg} \\
\mathrm{Q} 2 \mathrm{~W} \text { until unacceptable } \\
\text { toxicity, disease progression, } \\
\text { or investigator decision }\end{array}$ & $33 \%$ & $\begin{array}{l}\text { 12-month } \\
\text { PFS } 35 \%\end{array}$ & 23 & $\begin{array}{l}\text { Adil } \\
\text { Daud } \\
\text { (2015) } \\
{[136] ;} \\
\text { Ribas A } \\
\text { (2016) } \\
{[137]}\end{array}$ \\
\hline & & $\begin{array}{l}\text { Phase I } \\
\text { with } \\
\text { expansion } \\
\text { cohort }\end{array}$ & 173 & $\begin{array}{l}\text { Advanced melanoma } \\
\text { after at least } 2 \\
\text { ipilimumab doses }\end{array}$ & Unselected & $\begin{array}{l}\text { Pembrolizumab } 2 \text { mg/kg } \\
\text { IV every } 3 \text { week or } 10 \\
\text { mg/kg IV every } 3 \text { weeks }\end{array}$ & $26 \%$ & 2 & NA & $\begin{array}{l}\text { Robert } \\
\text { C (2014) } \\
{[138]}\end{array}$ \\
\hline & $\begin{array}{l}\text { NCT01848834 } \\
\text { (KEYNOTE-012) }\end{array}$ & Phase IB & 32 & $\begin{array}{l}\text { Metastatic triple- } \\
\text { negative breast } \\
\text { cancer }\end{array}$ & $\begin{array}{l}\text { PDL-1- } \\
\text { positive } \\
\text { tumor cells }\end{array}$ & $\begin{array}{l}\text { Pembrolizumab } 10 \\
\text { mg/kg IV every } 2 \\
\text { weeks }\end{array}$ & $19 \%$ & $\begin{array}{l}\text { 6-month } \\
\text { PFS } 23.3 \%\end{array}$ & NA & $\begin{array}{l}\text { Nanda } \\
\text { R (2014) } \\
{[139]}\end{array}$ \\
\hline & \multirow[t]{3}{*}{$\begin{array}{l}\text { NCT1905657 } \\
\text { (KEYNOTE-010) }\end{array}$} & \multirow[t]{3}{*}{ Phase II/III } & \multirow{3}{*}{$\begin{array}{l}1034 \text { all: } 339 \\
\text { pembrolizumab, } \\
343 \text { pembrolizumab, } \\
309 \text { docetaxel }\end{array}$} & \multirow{3}{*}{$\begin{array}{l}\text { Previously treated } \\
\text { PD-L1-positive } \\
\text { advanced NSCLC }\end{array}$} & \multirow{3}{*}{$\begin{array}{l}\text { PDL-1- } \\
\text { positive } \\
\text { tumor cells }\end{array}$} & $\begin{array}{l}\text { Pembrolizumab } 2 \text { mg/kg, } \\
\text { IV every } 3 \text { weeks }\end{array}$ & $18 \%$ & 3.9 months & 14.9 & \multirow{3}{*}{$\begin{array}{l}\text { Herbst } \\
\text { RS [2015] } \\
{[140]}\end{array}$} \\
\hline & & & & & & $\begin{array}{l}\text { Pembrolizumab } 10 \text { mg/kg, } \\
\text { IV every } 3 \text { weeks }\end{array}$ & $18.5 \%$ & 4.0 month & 17.3 & \\
\hline & & & & & & $\begin{array}{l}\text { Docetaxel, } 75 \text { mg/m2 } \\
\text { every } 3 \text { weeks }\end{array}$ & $9.3 \%$ & 4.0 month & 8.2 & \\
\hline & $\begin{array}{l}\text { NCT01953692 } \\
\text { (KEYNOTE-013) }\end{array}$ & Phase IB & 15 & Hodgkin lymphoma & Unselected & $\begin{array}{l}\text { Pembrolizumab } 10 \mathrm{mg} / \mathrm{kg} \\
\text { IV every } 2 \text { weeks up to } \\
2 \text { years }\end{array}$ & $53 \%$ & NA & NA & $\begin{array}{l}\text { Moskowitz } \\
\text { C (2014) } \\
{[141]}\end{array}$ \\
\hline \multirow[t]{4}{*}{$\begin{array}{l}\text { Atezolizumab } \\
\text { (MPDL3280A) }\end{array}$} & NCT01846416 & Phase II & 205 & NSCLC & $\begin{array}{l}\text { PD-L1- } \\
\text { positive } \\
\text { tumor cells }\end{array}$ & $\begin{array}{l}\text { Atezolizumab } 1200 \mathrm{mg} \\
\text { IV every } 3 \text { weeks }\end{array}$ & $\begin{array}{l}\text { The highest } \\
\text { ORR was } \\
\text { seen in pts } \\
\text { with PD-L1 } \\
\text { TC3 or IC3 } \\
\text { tumors }\end{array}$ & NA & NA & $\begin{array}{l}\text { Spigel } \\
\text { DR (2015) } \\
{[142]}\end{array}$ \\
\hline & \multirow[t]{2}{*}{$\begin{array}{l}\text { NCT01903993 } \\
\text { (POPLAR) }\end{array}$} & \multirow[t]{2}{*}{ Phase II } & \multirow[t]{2}{*}{287} & \multirow{2}{*}{$\begin{array}{l}\text { Previously treated } \\
\text { NSCLC patients (pts) } \\
\text { were stratified by } \\
\text { PD-L1 IC status }\end{array}$} & \multirow{2}{*}{$\begin{array}{l}\text { PD-L1- } \\
\text { positive } \\
\text { tumor cells }\end{array}$} & $\begin{array}{l}\text { Atezolizumab } 1200 \mathrm{mg} \\
\text { IV every } 3 \text { weeks }\end{array}$ & $57 \%$ & 2.7 & 12.6 & \multirow{2}{*}{$\begin{array}{l}\text { Spira } \\
\text { Al (2015) } \\
{[143] \text {; }} \\
\text { Fehrenbacher } \\
\text { L (2016) }\end{array}$} \\
\hline & & & & & & $\begin{array}{l}\text { Docetaxel } 75 \text { mg/m2 } \\
\text { IV every } 3 \text { weeks }\end{array}$ & $24 \%$ & 3.0 & 9.7 & \\
\hline & NCT01375842 & Phase I & 35 & Metastatic melanoma & $\begin{array}{l}\text { PD-L1- } \\
\text { positive } \\
\text { tumor cells }\end{array}$ & $\begin{array}{l}\text { Atezolizumab IV every } \\
3 \text { weeks for up to } 1 \text { year }\end{array}$ & $26 \%$ & $\begin{array}{l}\text { 24-week } \\
\text { PFS } 35 \%\end{array}$ & NA & $\begin{array}{l}\text { Omid } \\
\text { Hamid } \\
(2013) \\
{[144]}\end{array}$ \\
\hline
\end{tabular}


Table 2 Summary of reported clinical efficacy of PD-1/PD-L1 inhibitors (Continued)

\begin{tabular}{|c|c|c|c|c|c|c|c|c|c|c|}
\hline & & Phase I & 277 & Multiple cancer types & $\begin{array}{l}\text { PD-L1- } \\
\text { positive } \\
\text { tumor cells }\end{array}$ & $\begin{array}{l}\text { Atezolizumab intravenously } \\
\text { every } 3 \text { weeks doses }>1 \\
\mathrm{ml} / \mathrm{kg}\end{array}$ & $18 \%$ & 2.6 & NA & $\begin{array}{l}\text { Herbst } \\
\text { RS (2014) } \\
{[145]}\end{array}$ \\
\hline & \multirow[t]{4}{*}{ NCT01633970 } & Phase Ib & 37 & Untreated NSCLC & $\begin{array}{l}\text { PD-L1- } \\
\text { positive tumor cells }\end{array}$ & $\begin{array}{l}\text { Atezolizumab } 15 \mathrm{mg} / \mathrm{kg} \text { IV } \\
\text { every } 3 \text { weeks with } \\
\text { standard chemo dosing } \\
\text { for } 4-6 \text { cycles } \\
\text { followed by MPDL3280A } \\
\text { maintenance therapy until } \\
\text { progression }\end{array}$ & $67 \%$ & NA & NA & $\begin{array}{l}\text { Stephen } \\
\text { V (2015) } \\
{[146]}\end{array}$ \\
\hline & & \multirow[t]{2}{*}{ Phase Ib } & \multirow[t]{2}{*}{14} & \multirow[t]{2}{*}{$\begin{array}{l}\text { Arm A: refractory } \\
\text { metastatic colorectal } \\
\text { cancer; arm B: } \\
\text { oxaliplatin-naive } \\
\text { mCRC }\end{array}$} & \multirow[t]{2}{*}{$\begin{array}{l}\text { Not } \\
\text { mentioned }\end{array}$} & $\begin{array}{l}\text { Arm A: MPDL3280A } 20 \\
\mathrm{mg} / \mathrm{kg} \text { every } 3 \text { weeks and } \\
\text { bevacizumab (bev) } 15 \\
\mathrm{mg} / \mathrm{kg} \text { every } 3 \text { weeks }\end{array}$ & $\begin{array}{l}8 \%(1 / 13) \\
\text { in arm A }\end{array}$ & NA & NA & $\begin{array}{l}\text { Bendell, } \\
\text { J.C. (2015) } \\
{[147]}\end{array}$ \\
\hline & & & & & & $\begin{array}{l}\text { Arm B: MPDL3280A } 14 \\
\mathrm{mg} / \mathrm{kg} \text { every } 2 \text { weeks, bev } \\
10 \mathrm{mg} / \mathrm{kg} \text { every } 2 \text { weeks } \\
\text { and mFOLFOX6 at } \\
\text { standard doses }\end{array}$ & $\begin{array}{l}36 \%(9 / 25) \\
\text { in Arm B }\end{array}$ & NA & NA & \\
\hline & & Phase lb & 12 & $\begin{array}{l}\text { Metastatic renal } \\
\text { cell carcinoma }\end{array}$ & $\begin{array}{l}\text { Not } \\
\text { selected }\end{array}$ & $\begin{array}{l}\text { Atezolizumab } 15 \mathrm{mg} / \mathrm{kg} \\
\text { given alone on cycle } 1 \\
\text { day } 1 \text { and concurrently } \\
\text { with } 20 \mathrm{mg} / \mathrm{kg} \text { every } \\
2 \text { weeks thereafter }\end{array}$ & $40 \%$ & NA & NA & $\begin{array}{l}\text { Sznol } \\
M(2015) \\
{[148]}\end{array}$ \\
\hline \multirow[t]{4}{*}{$\begin{array}{l}\text { Durvalumab } \\
\text { (MEDI4736) }\end{array}$} & \multirow[t]{4}{*}{ NCT01693562 } & Phase I/II & 198 & NSCLC & $\begin{array}{l}\text { Tissue } \\
\text { available } \\
\text { for PD-L1 } \\
\text { biomarker } \\
\text { analysis }\end{array}$ & $\begin{array}{l}\text { Durvalumab } 10 \mathrm{mg} / \mathrm{kg} \text { IV } \\
\text { every } 2 \text { weeks until } \\
\text { unacceptable toxicity, } \\
\text { disease progression, or } \\
\text { for up to } 12 \text { months }\end{array}$ & $\begin{array}{l}14 \%(23 \% \\
\text { in PD-L1+ } \\
\text { tumors) }\end{array}$ & NA & NA & $\begin{array}{l}\text { Rizvi } \\
\text { NA (2015) } \\
{[149]}\end{array}$ \\
\hline & & Phase I & 13 & NSCLC & $\begin{array}{l}\text { Tissue } \\
\text { available } \\
\text { for PD-L1 } \\
\text { biomarker } \\
\text { analysis }\end{array}$ & $\begin{array}{l}\text { Durvalumab } 7 \text { doses } \\
(1-25) \text { across } 6 \text { cohorts } \\
(0.1-10 \mathrm{mg} / \mathrm{kg} \text { every } \\
2 \text { weeks; } 15 \mathrm{mg} / \mathrm{kg} \\
\text { every } 3 \text { weeks) }\end{array}$ & NA & NA & NA & $\begin{array}{l}\text { Brahmer } \\
\text { JR (2014) } \\
{[150]}\end{array}$ \\
\hline & & $\begin{array}{l}\text { Multi-arm } \\
\text { expansion } \\
\text { study }\end{array}$ & 62 & $\begin{array}{l}\text { A squamous cell } \\
\text { carcinoma of the } \\
\text { head and neck } \\
\text { expansion cohort }\end{array}$ & \multirow[t]{2}{*}{$\begin{array}{l}\text { Tissue } \\
\text { available } \\
\text { for PD-L1 } \\
\text { biomarker } \\
\text { analysis }\end{array}$} & $\begin{array}{l}\text { Durvalumab IV every } 2 \\
\text { weeks at } 10 \mathrm{mg} / \mathrm{kg} \text { for } \\
12 \text { months }\end{array}$ & $\begin{array}{l}12 \%(25 \% \\
\text { in PD-L1+ pts) }\end{array}$ & NA & NA & $\begin{array}{l}\text { Segal } \\
\mathrm{NH}(2015) \\
{[151]}\end{array}$ \\
\hline & & Phase I & 26 & $\begin{array}{l}\text { Advanced solid } \\
\text { tumors }\end{array}$ & & $\begin{array}{l}\text { Durvalumab IV every } 2 \\
\text { (q2w) or } 3 \text { weeks (q3w) } \\
\text { in a } 3+3 \text { dose escalation } \\
\text { with a } 28 \text {-day (q2w) or } \\
42 \text {-day ( } \mathrm{q} 3 \mathrm{w} \text { ) DLT window }\end{array}$ & NA & NA & NA & $\begin{array}{l}\text { Lutzky } \\
\text { J (2014) } \\
{[152]}\end{array}$ \\
\hline
\end{tabular}


Table 2 Summary of reported clinical efficacy of PD-1/PD-L1 inhibitors (Continued)

\begin{tabular}{|c|c|c|c|c|c|c|c|c|c|}
\hline NCT02088112 & Phase I & 10 & NSCLC & Unselect & $\begin{array}{l}\text { Durvalumab cohort A } \\
\text { received } 3 \mathrm{mg} / \mathrm{kg} \\
\text { (starting dose) every } \\
2 \text { weeks plus gefitinib } \\
250 \mathrm{mg} \text { QD }\end{array}$ & NA & NA & NA & $\begin{array}{l}\text { Creelan } \\
\text { BC (2015) } \\
{[153]}\end{array}$ \\
\hline \multirow[t]{3}{*}{ NCT02000947 } & \multirow[t]{3}{*}{ Phase Ib } & \multirow[t]{3}{*}{$\begin{array}{l}118 \\
\text { (102 eligible) }\end{array}$} & \multirow[t]{3}{*}{ NSCLC } & \multirow[t]{3}{*}{$\begin{array}{l}\text { Tissue } \\
\text { available } \\
\text { for PD-L1 } \\
\text { biomarker } \\
\text { analysis }\end{array}$} & $\begin{array}{l}\text { Durvalumab } 10-20 \mathrm{mg} / \mathrm{kg} \\
\text { every } 2 \text { or } 4 \text { weeks plus } \\
\text { tremelimumab } 1 \mathrm{mg} / \mathrm{kg} \\
(N=56)\end{array}$ & $\begin{array}{l}23 \%(6 / 26): \\
22 \%(2 / 9) \text { in } \\
\text { PD-L1+ } \\
\text { versus } 29 \% \\
\text { (4/14) in } \\
\text { PD-L1- }\end{array}$ & \multirow[t]{3}{*}{ NA } & NA & \multirow[t]{3}{*}{$\begin{array}{l}\text { Antonia } \\
\text { SJ (2015) } \\
\text { [154]; } \\
\text { Updated } \\
\text { in Antonia } \\
\text { SJ (2016) } \\
\text { [155] }\end{array}$} \\
\hline & & & & & $\begin{array}{l}\text { Durvalumab } 10-20 \text { mg/kg } \\
\text { every } 2 \text { weeks plus } \\
\text { tremelimumab } 3 \mathrm{mg} / \mathrm{kg} \\
(\mathrm{N}=34)\end{array}$ & $20 \%(5 / 25)$ & & & \\
\hline & & & & & $\begin{array}{l}\text { Durvalumab } 15 \mathrm{mg} / \mathrm{kg} \\
\text { every } 4 \text { weeks plus } \\
\text { tremelimumab } 10 \mathrm{mg} / \mathrm{kg} \\
(\mathrm{N}=9)\end{array}$ & $0 \%(0 / 9)$ & & & \\
\hline
\end{tabular}




\begin{tabular}{|c|c|c|c|c|}
\hline Specimen & \multicolumn{2}{|c|}{ Type of Assay } & Tumor-Derived Biomarker & Immune Cell-Derived Biomarker \\
\hline \multirow{4}{*}{ 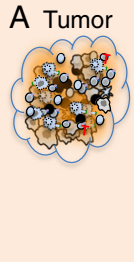 } & \multicolumn{2}{|c|}{$\begin{array}{l}\text { Protein (single } \\
\text { or multiplex } \\
\text { IHC) }\end{array}$} & PD-L1, PD-L2, TAAs & $\begin{array}{l}\text { CD8, CD4, CD3, CTLA-4, PD-1, } \\
\text { CD45RO, CD25, FOXP3, LAG-3, } \\
\text { CD11b, CD57, CD68, co-stimulator(s) }\end{array}$ \\
\hline & \multicolumn{2}{|c|}{ Genomics } & $\begin{array}{l}\text { WGS or WES for mutation } \\
\text { load, neoantigens, MMR genes }\end{array}$ & $\begin{array}{l}\text { T and/or B cell receptor deep } \\
\text { sequencing }\end{array}$ \\
\hline & \multicolumn{2}{|c|}{ Transcriptomics } & Multigene signatures & Multigene signatures, epigenomics \\
\hline & \multicolumn{2}{|c|}{ Function } & Proliferation marker: Ki67 & Ki67, granzyme B \\
\hline \multirow[t]{2}{*}{ B Blood } & \multicolumn{2}{|c|}{$\begin{array}{l}\text { Cell free } \\
\text { genomics or } \\
\text { proteomics }\end{array}$} & $\begin{array}{l}\text { ctDNA, ctRNA, miRNA, } \\
\text { exosomes }\end{array}$ & $\begin{array}{l}\text { miRNA; serological biomarkers (soluble } \\
\text { proteins, autoantibodies, cytokines or } \\
\text { chemokines; HLA haplotyping }\end{array}$ \\
\hline & \multicolumn{2}{|c|}{ Cell based } & CTCs & Immune cells \\
\hline \multicolumn{2}{|c|}{$\begin{array}{l}\mathrm{C} \text { Flow and } \\
\text { mass cytometry }\end{array}$} & \multicolumn{3}{|c|}{$\begin{array}{l}\text { Phenotypic and functional characterization of different immune cells } \\
\text { Activated T cells: CD3, CD4, CD8, Ki67, CTLA-4, PD-1, LAG-3, TIM-3, ICOS } \\
\text { Regulatory T cells: CD3, CD4, CD25, FOXP3, CD127, Ki67, CD45RA } \\
\text { Memory T cells: CD45RO } \\
\text { MDSC: CD14+HLA-DR } \\
\text { Detection and characterization of CTCs }\end{array}$} \\
\hline \multicolumn{2}{|c|}{$\begin{array}{l}\text { D Antigen- } \\
\text { specific T cell } \\
\text { monitoring }\end{array}$} & \multicolumn{3}{|c|}{$\begin{array}{l}\text { * Characterization of tumor-antigen specific T cells: } \\
\text { Sorting, Cloning, Binding avidity, Antigen-specific TCR } \alpha \text { and } \beta \\
\text { Functional assessment of response by tumor antigen-specific T cells: } \\
\text { HLA-class I and II tetramer, ELISPOT, Polyfunctional ICS, Natural tumor recognition }\end{array}$} \\
\hline
\end{tabular}

Fig. 2 Immune monitoring strategies for patients receiving checkpoint blockage therapy. Technologies that are currently used to assess the potential immune biomarkers. a Tumor and immune cells in tumor specimens could be evaluated by immunohistochemical stain (IHC) or immunofluorescence assays, molecular or genetic profiling analysis, and cellular functional assays. The tumor microenvironment can be dissected histopathologically to characterize spatial relationships between tumor and immune infiltrates. Transcriptional profiling assays can evaluate changes in gene expression in both the tumor cells and lymphocytes. Deep sequencing techniques enable quantification of changes in individual T/B cell clonotypes. b Peripheral blood provides a minimally invasive way to allow serial monitoring of dynamic changes of immune biomarkers during cancer immunotherapy. The analysis of changes in cell counts with therapy, changes in cytokine levels, circulating tumor cells, tumor-derived nucleotides, and immune cells. c Flow cytometric analysis of TILs anPBMCs for quantitating the effect of therapy on immune subsets such as activated CD8 + PD1 + T cells, CD4 + FOXP3 + CD25 hi Tregs, or myeloid-derived suppressor cells. Using polychromatic flow cytometry, multiple surface and intracellular markers can be detected, allowing in-depth characterization of T cell phenotype and activation state. d Multifunctional flow T cell assay, MHC tetramer staining and ELISPOT can be used to analyze the presence and function of tumor-specific T cell subpopulations. Abbreviations: PD-L1 programed death-1, IHC immunohistochemistry, ELISPOT enzyme-linked immunospot assay, CTCS circulating tumor cells, WES whole exome sequencing, NGS next-generation sequencing, TIM-3 T cell immunoglobulin domain and mucin domain, LAG lymphocyte-activation gene, ICOS inducible costimulators, MDSC myeloid-derived suppressor cells, HLA human leukocyte antigen

improved clinical outcome [76-78], regardless of cancer treatment. TIL counts are primarily measured by IHC [79]. Recent development of multicolored immunohistochemistry staining resulted in a multiplex of up to seven fluorescent dyes effectively interrogated in microscopes equipped with a multispectral camera [80]. The multispectral fluorescent IHC with a panel including CD3, CD8, FoxP3, CD163, and PD-L1 was used to quantify the density of TIL subpopulation in advanced melanoma patients.

\section{Flow cytometry staining}

Flow cytometry traditionally uses fluorochrome-labeled antibodies to identify cellular protein expression of the target cells. Flow cytometric analysis of peripheral blood mononuclear cells (PBMCs) and TILs can quantitate the effect of therapy on low-frequency immune subsets such as Treg, MDSC, and activated $\mathrm{CD}^{+} \mathrm{T}$ cells [81]. The biggest advantage of flow cytometry is the combination of multiparameter measurements in a high-throughput manner. With recent advances in laser and fluorochrome technology, commercially available systems allow for detection of up to 18 colors at analysis rates of more than 20,000 events per second. This tremendous power allows for the analysis of multiple characteristics of rare cells such as tumor antigen-specific T-lymphocytes, including their phenotype and functional activity [82]. Flow cytometric assays are currently widely used for the enumeration and phenotypic characterization of lymphocytes, measuring cytokines, secreted molecules, intracellular signaling, function, and cell proliferation [83]. Using polychromatic flow cytometry, multiple surface and intracellular markers can be detected, allowing in-depth characterization of $\mathrm{T}$ cell phenotype and activation state [84]. In addition to flow cytometry, antigen-loaded soluble major histocompatibility complex (MHC) tetramer stains can be used to analyze tumor-specific $\mathrm{T}$ cell subpopulations [82]. This tetramer/pentamer staining has been used for phenotypic and quantitative analysis of antigenspecific CD8 T cells $[85,86]$. The human leukocyte antigen (HLA) system is a gene complex encoding the MHC 
Table 3 Currently available translational biomarker assays for immune checkpoint inhibitors

\begin{tabular}{|c|c|c|c|c|c|}
\hline Biospecimen & Method & Tissue/cell types & Pros & Cons & $\begin{array}{l}\text { References and } \\
\text { recommended reading }\end{array}$ \\
\hline \multirow[t]{4}{*}{ FFPE } & $\mathrm{IHC}$ & $\begin{array}{l}\text { Tumor cells or tumor } \\
\text { infiltrating immune } \\
\text { cells }\end{array}$ & $\begin{array}{l}\text { Direct detection; accurately pinpoint cancer cells; } \\
\text { highly sensitive; simplicity; low cost }\end{array}$ & $\begin{array}{l}\text { Requirement of trained pathologists; inconsistency } \\
\text { for criteria used to score tumors such as } \\
\text { PD-L1-positive or negative }\end{array}$ & $\begin{array}{l}\text { Herbst R (2014) [145]; } \\
\text { Loughlin PA (2007) [164] }\end{array}$ \\
\hline & Multicolor IHC & $\begin{array}{l}\text { Tumor cells or tumor } \\
\text { infiltrating immune } \\
\text { cells }\end{array}$ & $\begin{array}{l}\text { Broad dynamic range; capability for multiplexing } \\
\text { using different fluorescence channels; }>10 \\
\text { protein targets are identified in the same sample; } \\
\text { amenability for co-localization studies }\end{array}$ & $\begin{array}{l}\text { Absence of rigorous quantitative tests; limitation } \\
\text { in some biomarker-driven clinical trials; user must } \\
\text { select combinations of dyes }\end{array}$ & $\begin{array}{l}\text { Carvajal-Hausdorf DE } \\
\text { (2014) [165] }\end{array}$ \\
\hline & $\begin{array}{l}\text { T cell receptor } \\
\text { deep sequencing }\end{array}$ & TILS & $\begin{array}{l}\text { T cell count information; } \\
\text { T cell clonality in tumor }\end{array}$ & Heterogeneous expression of TIL & Robbins HS (2013) [100] \\
\hline & $\begin{array}{l}\text { Whole exome } \\
\text { sequencing (WES) }\end{array}$ & Tumor cells & $\begin{array}{l}\text { Characterization of tumor mutation load including } \\
\text { nucleotide substitutions; structural rearrangements } \\
\text { and copy number alterations; identification of the } \\
\text { neoantigens and neoepitopes; affordable cost }\end{array}$ & $\begin{array}{l}\text { Require high-performance deep sequencing, } \\
\text { computational bioinformatics support; } \\
\text { The pipelines are still at early developmental phase }\end{array}$ & $\begin{array}{l}\text { Snyder A (2014) [104]; } \\
\text { Rizvi NA (2015) [105]; } \\
\text { Bouffet E (2016) [107]; } \\
\text { Chen K-H (2016) [166] } \\
\text { Hugo W (2016) [106] }\end{array}$ \\
\hline \multirow[t]{7}{*}{ Blood } & $\begin{array}{l}\text { ELISPOT assays } \\
\text { (IFNy and granzyme B) }\end{array}$ & $\mathrm{T}$ cells in PBMCs & $\begin{array}{l}\text { Detection of tumor antigen-specific } \mathrm{CD}^{+} \text {and } \\
\mathrm{CD} 8^{+} T \text { cell response with good assay sensitivity; } \\
\text { Relatively well validated assay }\end{array}$ & $\begin{array}{l}\text { A poor correlation with clinically relevant } \\
\text { immune responses }\end{array}$ & $\begin{array}{l}\text { Shafer-Weaver K } \\
\text { (2006) [167]; } \\
\text { Janetzki S (2008) [95] } \\
\text { Malyguine A (2012) [94]; } \\
\text { Janetzki S (2015) [93]; }\end{array}$ \\
\hline & $\begin{array}{l}\text { Flow cytometry (tetramer, } \\
\text { polyfunctional analysis) }\end{array}$ & T cells in PBMCs & $\begin{array}{l}\text { Assessment of tumor antigen-specific } C D 4^{+} \text {and } \\
\mathrm{CD} 8^{+} \mathrm{T} \text { cells response; measure multiple functions; } \\
\text { detection of neoantigen-specific CD8 }+ \text { PD- } 1+\mathrm{T} \\
\text { cells; minimally invasive }\end{array}$ & $\begin{array}{l}\text { Merely in lab research, not as routine clinical } \\
\text { monitoring yet }\end{array}$ & $\begin{array}{l}\text { Yuan J (2008) [84]; } \\
\text { Attic S (2011) [85]; } \\
\text { McNeil LK (2013) [86]; } \\
\text { Barrera L (2015) [168]; } \\
\text { Gros A (2016) [118] }\end{array}$ \\
\hline & $\begin{array}{l}\text { Flow cytometry } \\
\text { phenotype staining }\end{array}$ & $\begin{array}{l}\text { Whole blood immune } \\
\text { phenotype }\end{array}$ & $\begin{array}{l}\text { Analyses of the frequency and proliferation of } \\
\text { different subsets of immune cells; routine operation }\end{array}$ & $\begin{array}{l}\text { Dedicated resource and staff to perform } \\
\text { the analyses }\end{array}$ & $\begin{array}{l}\text { Streitz M (2013) [169]; } \\
\text { van Dongen JJ (2012) } \\
{[170]}\end{array}$ \\
\hline & RNA-Seq (NGS) & T cells in PBMCs & $\begin{array}{l}\text { Identification of genetic variants; a broader dynamic } \\
\text { range; detection of more differentially expressed } \\
\text { genes; fast and high efficiency }\end{array}$ & $\begin{array}{l}\text { More expensive than microarray; more complex } \\
\text { for analysis; bulk signature, not single cell signals; } \\
\text { need more validation }\end{array}$ & Zhao S (2010) [171] \\
\hline & qPCR assay & T cells in PBMCs & $\begin{array}{l}\text { High specificity; able to detect the reactivity of } \\
\text { low-frequency T cells in the peripheral blood of } \\
\text { metastatic cancer patients }\end{array}$ & $\begin{array}{l}\text { Bulk signature, not single cell signals; need more } \\
\text { validation }\end{array}$ & Kammula US (2008) [172] \\
\hline & Flow cytometry & CTCS & $\begin{array}{l}\text { Qualitative analysis at the single cell level in a } \\
\text { relatively short period of time; decrease the amount } \\
\text { of blood needed; provide valuable information } \\
\text { regarding the frequency, phenotype and/or the } \\
\text { functionality of T cells }\end{array}$ & Expensive; need more validation & Zaritskaya L (2010) [83] \\
\hline & $\begin{array}{l}\text { Cell sieve microfiltration } \\
\text { assay and QUASR } \\
\text { technique }\end{array}$ & CTCS & $\begin{array}{l}\text { PD-L1 levels from CTCs or CAMLs serves as a } \\
\text { surrogate for PD-L1 expression in tumor; as a } \\
\text { marker for immunotherapy response }\end{array}$ & Limited in lab research; need more validation & $\begin{array}{l}\text { Steven HL (2015) [173]; } \\
\text { Adams DL (2014) [174] }\end{array}$ \\
\hline
\end{tabular}


Table 4 Immunohistochemistry assays for PD-L1 expression

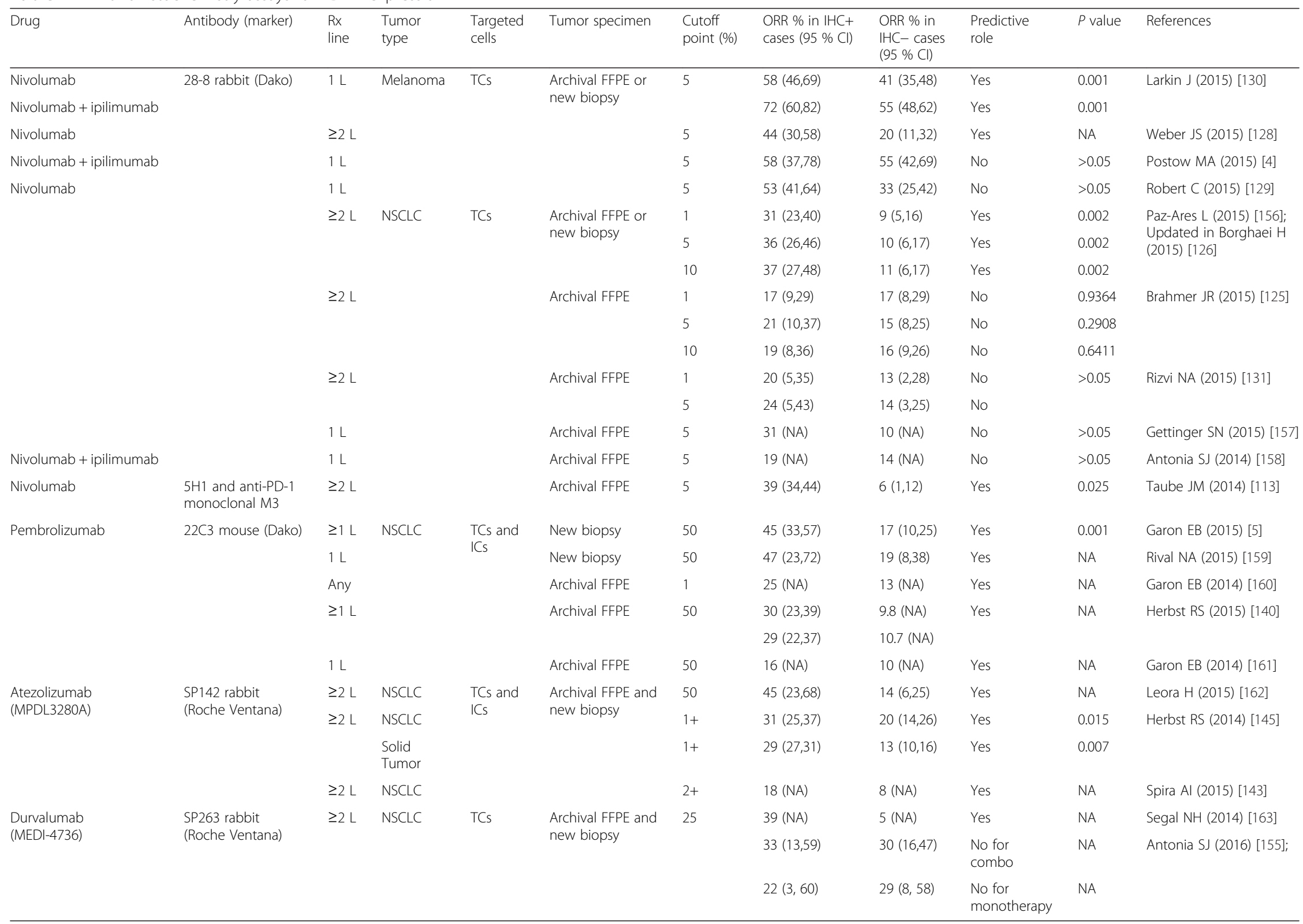


proteins in humans. HLA-peptide complexes binding to $\mathrm{T}$ cell receptors could further define the specificity for epitopes and alleles [87]. Recently, mass cytometry or CyTOF which replace the fluorescent labels with heavy metal ions is under investigation for its application in immune biomarker research [88].

\section{ELISA and protein microarray}

Biomarkers in the blood have been pursued because specimens are easy to collect and assays are available for serial monitoring and quantitative measurements [89]. Enzymelinked immunoabsorbent assay (ELISA) is widely used to assess the production of soluble mediators such as cytokines, chemokines, and tumor antigen-specific antibodies in peripheral blood before and after treatment. Novel protein microarray technologies such as ProtoArray ${ }^{\circ}$ are available to analyze the serological response of up to 9000 proteins simultaneously [90-92].

\section{ELISPOT}

Enzyme-linked immunospot (ELISPOT) assays are robust and standardized tests that quantify both the frequency and function of $\mathrm{T}$ or $\mathrm{B}$ cells at the single cell level. Both PBMCs and isolated $\mathrm{CD} 4^{+}$and $\mathrm{CD}^{+} \mathrm{T}$ cell subsets could be stimulated by antigens and cultured in a 96-well plate with a nitrocellulose membrane coated with antibodies for cytokines of interest. These assays, such as the IFN $\gamma$ ELISPOT, have gained increasing popularity for monitoring clinical trials and in basic research [93-95]. Results from various clinical trials, including peptide and whole tumor cell vaccination and cytokine treatment, showed the suitability of the IFN $\gamma$ ELISPOT assay for monitoring $\mathrm{T}$ cell response [96]. ELISPOT assays revealed that $75 \%$ of melanoma patients vaccinated with antigenic peptide demonstrated specific immune responses [97, 98]. Besides IFN $\gamma$, other cytokines such as IL-2, IL-5, IL-10, IL-17, granzyme B, TNF, and granulocyte-macrophage colony-stimulating factor (GM-CSF) are commonly measured by ELISPOT assays. It has been expanded to more than $2 \sim 3$ parameters with the introduction of fluorescent dyes [99].

\section{$T$ cell or B cell receptor deep sequencing}

To develop a robust, quantitative method with high reproducibility, Robins et al. [100] uses a digital droplet PCR technique call a QuanTILfy assay. High-throughput quantitative sequencing of the rearranged TCR $\beta$ genes uses the ImmunoSeq assay. The TCR loci undergo somatic gene rearrangements in the 52 variable $(\mathrm{V})$, diversity (D), and 13 joining (J) regions of the $\beta$ chain and variable $(\mathrm{V})$ and joining $(\mathrm{J})$ regions of $\alpha$ chain. There are 52 $\mathrm{V} \beta$ segments and $13 \mathrm{~J} \beta$ segments that can rearrange. With the right TaqMan probes-DNA from $\mathrm{T}$ cells can be easily identified with reference to total DNA, as was shown when purified human $\mathrm{T}$ cells were obtained from a healthy donor and then diluted and mixed with human lung fibroblasts at different ratios. This technique can also identify clonal expansion (the mark of the adaptive immune response). TCR deep sequencing has been used to show the correlation between TCR repertoire and clinical response to cancer immunotherapy in patients with melanoma or prostate cancer treated with ipilimumab [101]. Creation of a responder library for TCR repertoire will greatly advance the field, especially for genetically modified TCR cell transfer therapy.

\section{WES for mutation load}

The cancers that respond best to PD-1 inhibitors, such as advanced melanoma and NSCLC, are the tumor types that are genetically very complex with a high nonsynchronous mutation load. This discovery led to an interest in neoantigens (i.e., tumor-specific mutant antigens (TSMAs)) that are immunogenic [102]. The advances in both affordable next-generation sequencing (NGS) technology and bioinformatics make it feasible to assess the full mutation load in individual tumors and to identify neoantigens by comparing WGS of tumor and normal tissues [103]. Computation prediction algorithms and the tandem mini-gene library allow for the evaluation of the immunogenicity of both $\mathrm{CD}^{+}$and $\mathrm{CD}^{+}{ }^{+} \mathrm{T}$ cell neoepitopes. Mutation load and neoepitopes have been explored for their correlation with clinical outcomes in cancer patients treated with the PD-1/PD-L1 immune checkpoint blockade [104-107]. However, whole exome sequencing (WES) currently is not used in routine clinical practice. The role of tumor load assessed in targeted exome sequencing (TES) assays in predicting response to immune checkpoint inhibitors remains to be determined.

\section{Genetic susceptibility}

Genetic factors are known to modulate the immune response to a therapeutic protein product. In particular, some HLA haplotypes may predispose patients to developing either exceptional or undesirable antibody responses to immune checkpoint blockage therapies [108]. If both are appropriate and feasible, HLA mapping studies may help define a subset of patients who are at increased risk. Moreover, genetic polymorphisms in cytokine genes may upregulate or downregulate immune responses [109], which is why the FDA recommends that researchers evaluate the genetic factors that may modulate the immune response to a therapeutic protein. For example, the subset of patients who generate neutralizing antibodies to IFN $\beta$ products are more likely to possess distinct HLA haplotypes [108]. Thus, knowledge of the heightened susceptibility of patients with such HLA haplotypes may guide us to prevent such responses or pursuit 
other treatment options (http://www.fda.gov/ucm/groups/ fdagov-public/@fdagov-drugs-gen/documents/document/ ucm338856.pdf).

\section{Tumor-derived immune biomarkers PD-L1 expression}

Upregulation of PD-L1 expression level has been reported in many different cancer types (e.g., melanoma (40-100 \%), NSCLC (35-95\%), and multiple myeloma (93 \%)). High levels of PD-L1 expression have been linked to poor clinical outcomes [42, 110, 111]. Until now, anti-PD-L1 IHC on tumor specimens is the most commonly used biomarker for selecting patients who are likely to respond to treatments [89]. Constitutively overexpressed PD-L1 in melanoma is associated with poor clinical outcome [112]. However, the PD-L1 overexpression in the context of CD8-positive cells is associated with a better prognosis [113]. Although PD-L1 IHC using the $22 \mathrm{C} 3$ antibody has been approved by the US FDA as the only predictive companion diagnostic for selecting NSCLC patients for pembrolizumab, tumor responses have been seen in low PD-L1-expressing tumors. Conflicting results have been reported with other PD-L1 antibodies and drugs. Table 4 summarizes the reported data of PD-L1 IHC in current clinical trials.

Several tumor characteristics, such as a high mutation load, smoking-related tumors, and tumors with mismatch repair genes are associated with improved objective tumor response rate (ORR), durable clinical benefit (DCB), and PFS to immune checkpoint blockade antibodies. Notably, whole exome sequencing has revealed that a nonsynonymous mutation load of $>200$ per tumor correlates with clinical responses to $\mathrm{PD}-1 \mathrm{mAb}$ in NSCLC, melanoma, and colorectal cancer with microsatellite instability (MSI; i.e., mutations in DNA mismatch repair genes) [114-116]. Rizvi and his colleagues showed that mutation load correlates with improved ORR (63 versus $0 \%$ ), DCB (73 versus $13 \%$ ), and PFS (14.5 versus 3.7 months) [105]. Moreover, the efficacy was associated with a molecular smoking signature. The ORR was 56 and $17 \%$ in transversion-high tumors and transversion-low tumors, respectively; the rate of $\mathrm{DCB}$ was 77 versus $22 \%$, respectively; and the PFS was also significantly longer in transversion-high tumors compared to transversion-low tumors. Efficacy was also connected with higher neoantigen burden, but additional genetic features are likely to play a role in determining the tumor response $[116,117]$. Neoantigen-specific CD8+ $\mathrm{T}$ cell responses paralleled tumor regression in one responder, implying that anti-PD-1 therapy enhanced neoantigen-specific $T$ cell reactivity [118].

\section{Immune cell-derived biomarkers}

TIL cells have been shown to express significantly higher levels of PD-1 than T cells in normal tissue [119]. The tumor microenvironment may secrete pro-inflammatory cytokines to upregulate the expression of PD-1 on TIL cells to ensure that they can respond to the high levels of PD-L1 expressed on the tumor [120]. Preexisting $\mathrm{CD}^{+} \mathrm{T}$ cells distinctly located at the invasive tumor margin are associated with expression of the PD-1/PD-L1 immune inhibitory axis [121]. The proliferation of intratumoral $\mathrm{CD}^{+} \mathrm{T}$ cells directly correlated with radiographic reduction in tumor size in metastatic melanoma patients treated with pembrolizumab. Pretreatment samples obtained from responding patients showed higher numbers of $\mathrm{CD}^{+} \mathrm{T}$ cells, PD-1, and PD-L1-expressing cells at the invasive tumor margin and inside tumors, with a more clonal TCR repertoire. Using multivariate analysis, researchers established a predictive model based on CD8 expression at the invasive margin and validated the model in an independent cohort of 15 patients. Their findings indicate that tumor regression after PD-1 blockade requires preexisting $\mathrm{CD}^{+} \mathrm{T}$ cells that are negatively regulated by PD-1/PD-L1-mediated adaptive immune resistance. In addition, the tumor microenvironment can be dissected histopathologically in order to characterize spatial relationships between tumor and immune infiltrate, and transcriptional profiling assays can evaluate changes in gene expression in both the tumor and in lymphocytes [122].

Given that TIL in the tumor microenvironment affects the prognosis of the tumor, a new TNM Immune system (TNM-I) system has been proposed and is currently being validated by an international consortium [123]. Early studies suggest that activated $\mathrm{T}$ cells are not pharmacodynamic markers of nivolumab treatment [124]. It remains to be determined whether nivolumab treatment increases CD8 effector memory cells in cancer patients. With technical advances, detection of CD8-positive, PD-1-positive T cells in the peripheral blood of melanoma patients receiving PD-1 inhibitors is feasible. Furthermore, the tumor-antigen specificities and TCR repertoires of the circulating and tumor-infiltrating CD ${ }^{+} \mathrm{PD}-1^{+}$cells appeared similar [118].

\section{Conclusions}

The era of cancer immunotherapy has arrived. This major breakthrough in cancer treatment holds great promise for increasing cure rates for patients with various cancer types in multiple disease settings. Checkpoint blockade antibodies targeting CTLA-4, PD-1, and PD-L1 axis have demonstrated impressive and durable disease control and promising responses in patients with multiple tumor types. Despite these advances, only a subset of patients benefits from immune checkpoint blockade therapies, with some patients experiencing mechanismbased irAEs. Translational biomarker research is one way to overcome these limitations of therapy. Biomarkers play a critical role in understanding potential 
mechanisms of action in patients, identifying patients who are likely to respond to the growing list of cancer therapeutics and avoiding the irAEs. Several tumor-derived biomarkers have been reported from recent correlative studies including PD-L1 expression on tumor cells, high tumor mutational load, and neoantigens. In addition, several immune cell-derived biomarkers showed better correlation with the clinical outcomes. The presence of TILs in tumor microenvironments, increased PDL1 expression on immune cells, and the ratio of effector $\mathrm{CD}^{+}{ }^{\mathrm{T}}$ cells to FoxP3 ${ }^{+}$regulatory $\mathrm{T}$ cells in tumors are some examples of markers for clinical outcomes. Future studies are warranted to harmonize companion diagnostics (such as PD-L1 IHC) for accurate clinical assessment and application of the class of PD-1/PD-L1 inhibitors. It is of importance to further evaluate mutation load as a potential biomarker and develop effective tumor antigen-specific $\mathrm{T}$ cell assays to differentiate immunogenic neoepitopes from putative ones. The advances in translational immune biomarker research are essential for personalized cancer immunotherapy as either monotherapy or combinational therapy.

\section{Abbreviations}

AKT, protein kinase B; APCs, antigen-presenting cells; BRAF, B-raf and v-raf murine sarcoma viral oncogene homologue B1; BTLA, B- and T-lymphocyte attenuator; CAMLs, cancer-associated macrophage-like cells; CEACAM, carcinoembryonic antigen-related cell adhesion molecule; CTCs, circulating tumor cells; CTL, cytotoxic T-lymphocytes; CTLA-4, cytotoxic T-lymphocyteassociated protein 4; DC, dendritic cell; DLT, dose-limiting toxicity; EGFR, epidermal growth factor receptor; ELISPOT, enzyme-linked immunospot assay; FFPE, formalin-fixed paraffin-embedded; GITR, glucocorticoid-induced tumor necrosis factor receptor; GM-CSF, granulocyte-macrophage colonystimulating factor; HLA, human leukocyte antigen; HVEM, herpes virus entry mediator; ICOS, inducible costimulators; IDO, indoleamin 2,3-dioxygenase; $I H C$, immunohistochemistry; IL-2R, IL-2 receptor; irAEs, immune-related adverse effects; JNK, c-Jun N-terminal kinase; LAG, lymphocyte-activation gene; MDSCs, myeloid-derived

suppressor cells; MEK/ERK, mitogen/extracellular signal regulated kinase; MHC, major histocompatibility complex; NGS, next-generation sequencing; NFKB, nuclear factor kappa-light-chain-enhancer of activated B cells; NSCLC, non-smallcell lung cancer; PBMCs, peripheral blood

mononuclear cells; PD-1, programed death-1; PD-L1, programed cell-death ligand 1; PI3K, phosphatidylinositol 3-kinase; q2W, every 2 weeks; q3W, every 3 weeks; q4w, every 4 weeks; QD, once daily; STAT, signal transducer and activator of transcription; Teff, effector T cell; TGF- $\beta$, transforming growth factor beta; TIGIT,

T cell immunoreceptor with Ig and ITIM domains; TIL, tumor-infiltrating lymphocytes; TIM-3, T cell immunoglobulin domain and mucin domain; TNF, tumor necrosis factors; Treg, regulatory T cells; TSMA, tumor-specific mutant antigen; VEGF, vascular endothelial growth factor; WES, whole exome sequencing
}

\section{Acknowledgements}

None.

\section{Funding}

None.

\section{Availability of data and materials}

The dataset supporting the conclusions of this article is included within the article.

\section{Authors' contributions}

WM, JY, and TL contributed to the conception and design of the study. WM, JY, and TL carried out the development of methodology. WM, JY, and $\mathrm{TL}$ analyzed and interpreted the data. WM, BMG, JY, and TL wrote, reviewed, revised, and approved the final submission of the study. All authors read and approved the final manuscript.

\section{Competing interests}

JY owns a TCR sequencing patent with Adaptive Biotechnologies.

Consent for publication

Not applicable.

\section{Author details}

${ }^{1}$ Division of Hematology \& Oncology, Department of Internal Medicine, University of California Davis Comprehensive Cancer Center, University of California, Davis, School of Medicine, 4501 X Street, Suite 3016, Sacramento, CA 95817, USA. VA Northern California Health Care System, 10535 Hospital Way, Mather, CA 95655, USA. ${ }^{3}$ Former visiting medical student from School of Medicine, Peking University Health Science Center, No. 38 Xueyuan Road, Beijing 100191, China. ${ }^{4}$ Immune Monitoring Core, Ludwig Center for Cancer Immunotherapy, Memorial Sloan Kettering Cancer Center, 1275 York Ave, Box 386, New York NY10065, USA. ${ }^{5}$ Present address: Oncology Clinical Research, Merck Research Laboratories, Rahway NJ07065, USA.

Received: 11 March 2016 Accepted: 20 May 2016

Published online: 27 May 2016

\section{References}

1. Webster RM. The immune checkpoint inhibitors: where are we now? Nat Rev Drug Discov. 2014;13(12):883-4.

2. Wolchok JD, Hoos A, O'Day S, Weber JS, Hamid O, Lebbe C, et al. Guidelines for the evaluation of immune therapy activity in solid tumors: immunerelated response criteria. Clin Cancer Res. 2009;15(23):7412-20.

3. Hodi FS, Hwu WJ, Kefford R, Weber JS, Daud A, Hamid O, et al. Evaluation of immune-related response criteria and RECIST v1.1 in patients with advanced melanoma treated with pembrolizumab. J Clin Oncol. 2016;34(13):1510-7.

4. Postow MA, Chesney J, Pavlick AC, Robert C, Grossmann K, McDermott D, et al. Nivolumab and ipilimumab versus ipilimumab in untreated melanoma. N Engl J Med. 2015;372(21):2006-17.

5. Garon EB, Rizvi NA, Hui R, Leighl N, Balmanoukian AS, Eder JP, et al. Pembrolizumab for the treatment of non-small-cell lung cancer. N Engl J Med. 2015;372(21):2018-28.

6. Smith AD, Roda D, Yap TA. Strategies for modern biomarker and drug development in oncology. J Hematol Oncol. 2014;7:70.

7. Pico de Coana Y, Choudhury A, Kiessling R. Checkpoint blockade for cancer therapy: revitalizing a suppressed immune system. Trends Mol Med. 2015; 21(8):482-91.

8. Sharma P, Allison JP. Immune checkpoint targeting in cancer therapy: toward combination strategies with curative potential. Cell. 2015;161(2):205-14.

9. Ruffell B, Coussens LM. Macrophages and therapeutic resistance in cancer. Cancer Cell. 2015;27(4):462-72.

10. Coffelt SB, de Visser KE. Immune-mediated mechanisms influencing the efficacy of anticancer therapies. Trends Immunol. 2015;36(4):198-216.

11. Woo SR, Corrales L, Gajewski TF. The STING pathway and the T cell-inflamed tumor microenvironment. Trends Immunol. 2015;36(4):250-6.

12. Goel G, Sun W. Advances in the management of gastrointestinal cancers - an upcoming role of immune checkpoint blockade. J Hematol Oncol. 2015;8:86.

13. Chen DS, Irving BA, Hodi FS. Molecular pathways: next-generation immunotherapy -inhibiting programmed death-ligand 1 and programmed death-1. Clin Cancer Res. 2012;18(24):6580-7.

14. Topalian SL, Weiner GJ, Pardoll DM. Cancer immunotherapy comes of age. J Clin Oncol. 2011;29(36):4828-36.

15. Dunn GP, Old LJ, Schreiber RD. The three Es of cancer immunoediting. Annu Rev Immunol. 2004;22:329-60.

16. Hacohen N, Fritsch EF, Carter TA, Lander ES, Wu CJ. Getting personal with neoantigen-based therapeutic cancer vaccines. Cancer Immunol Res. 2013;1(1):11-5.

17. Kim R, Emi M, Tanabe K. Cancer immunoediting from immune surveillance to immune escape. Immunology. 2007;121(1):1-14. 
18. Stewart TJ, Abrams SI. How tumours escape mass destruction. Oncogene. 2008;27(45):5894-903.

19. Terme M, Pernot S, Marcheteau E, Sandoval F, Benhamouda N, Colussi O, et al. VEGFA-VEGFR pathway blockade inhibits tumor-induced regulatory T-cell proliferation in colorectal cancer. Cancer Res. 2013;73(2):539-49.

20. Barber DL, Wherry EJ, Masopust D, Zhu B, Allison JP, Sharpe AH, et al. Restoring function in exhausted CD8 T cells during chronic viral infection. Nature. 2006;439(7077):682-7.

21. Kim PS, Ahmed R. Features of responding T cells in cancer and chronic infection. Curr Opin Immunol. 2010:22(2):223-30

22. Bertrand A, Kostine M, Barnetche T, Truchetet ME, Schaeverbeke T. Immune related adverse events associated with anti-CTLA-4 antibodies: systematic review and meta-analysis. BMC Med. 2015;13:211.

23. Corsello SM, Barnabei A, Marchetti P, De Vecchis L, Salvatori R, Torino F. Endocrine side effects induced by immune checkpoint inhibitors. J Clin Endocrinol Metab. 2013;98(4):1361-75

24. Johnson DB, Sullivan RJ, Ott PA, Carlino MS, Khushalani NI, Ye F, et al. Ipilimumab therapy in patients with advanced melanoma and preexisting autoimmune disorders. JAMA Oncol. 2016;2(2):234-40.

25. Keir ME, Butte MJ, Freeman GJ, Sharpe AH. PD-1 and its ligands in tolerance and immunity. Annu Rev Immunol. 2008;26:677-704.

26. Dorfman DM, Brown JA, Shahsafaei A, Freeman GJ. Programmed death-1 (PD-1) is a marker of germinal center-associated T cells and angioimmunoblastic T-cell lymphoma. Am J Surg Pathol. 2006;30(7):802-10.

27. Ohaegbulam KC, Assal A, Lazar-Molnar E, Yao Y, Zang X. Human cancer immunotherapy with antibodies to the PD-1 and PD-L1 pathway. Trends Mol Med. 2015:21(1):24-33.

28. Yamazaki T, Akiba H, Iwai H, Matsuda H, Aoki M, Tanno Y, et al. Expression of programmed death 1 ligands by murine T cells and APC. J Immunol. 2002;169(10):5538-45.

29. Eppihimer MJ, Gunn J, Freeman GJ, Greenfield EA, Chernova T, Erickson J, et al. Expression and regulation of the PD-L1 immunoinhibitory molecule on microvascular endothelial cells. Microcirculation. 2002;9(2):133-45.

30. Schreiner B, Mitsdoerffer M, Kieseier BC, Chen L, Hartung HP, Weller M, et al Interferon-beta enhances monocyte and dendritic cell expression of $\mathrm{B} 7-\mathrm{H} 1$ (PD-L1), a strong inhibitor of autologous T-cell activation: relevance for the immune modulatory effect in multiple sclerosis. J Neuroimmunol. 2004; 155(1-2):172-82.

31. Formenti SC, Demaria S. Combining radiotherapy and cancer immunotherapy: a paradigm shift. J Natl Cancer Inst. 2013;105(4):256-65.

32. Twyman-Saint Victor C, Rech AJ, Maity A, Rengan R, Pauken KE, Stelekati E, et al. Radiation and dual checkpoint blockade activate non-redundant immune mechanisms in cancer. Nature. 2015;520(7547):373-7.

33. Daly ME, Monjazeb AM, Kelly K. Clinical trials integrating immunotherapy and radiation for non-small-cell lung cancer. J Thorac Oncol. 2015;10(12):1685-93.

34. Ramakrishnan R, Assudani D, Nagaraj S, Hunter T, Cho HI, Antonia S, et al. Chemotherapy enhances tumor cell susceptibility to CTL-mediated killing during cancer immunotherapy in mice. J Clin Invest. 2010;120(4):1111-24.

35. Zitvogel L, Galluzzi L, Smyth MJ, Kroemer G. Mechanism of action of conventional and targeted anticancer therapies: reinstating immunosurveillance. Immunity. 2013;39(1):74-88.

36. Ma Y, Adjemian S, Mattarollo SR, Yamazaki T, Aymeric L, Yang $H$, et al. Anticancer chemotherapy-induced intratumoral recruitment and differentiation of antigen-presenting cells. Immunity. 2013;38(4):729-41.

37. Vincent J, Mignot G, Chalmin F, Ladoire S, Bruchard M, Chevriaux A, et al. 5-Fluorouracil selectively kills tumor-associated myeloid-derived suppressor cells resulting in enhanced T cell-dependent antitumor immunity. Cancer Res. 2010;70(8):3052-61.

38. Kanterman J, Sade-Feldman M, Biton M, Ish-Shalom E, Lasry A, Goldshtein A et al. Adverse immunoregulatory effects of 5FU and CPT11 chemotherapy on myeloid-derived suppressor cells and colorectal cancer outcomes. Cancer Res. 2014;74(21):6022-35.

39. Butte MJ, Keir ME, Phamduy TB, Sharpe AH, Freeman GJ. Programmed death-1 ligand 1 interacts specifically with the B7-1 costimulatory molecule to inhibit T cell responses. Immunity. 2007;27(1):111-22.

40. Benson Jr DM, Bakan CE, Mishra A, Hofmeister CC, Efebera Y, Becknell B, et al. The PD-1/PD-L1 axis modulates the natural killer cell versus multiple myeloma effect: a therapeutic target for CT-011, a novel monoclonal antiPD-1 antibody. Blood. 2010;116(13):2286-94.

41. Iwai $Y$, Ishida M, Tanaka Y, Okazaki T, Honjo T, Minato N. Involvement of PD-L1 on tumor cells in the escape from host immune system and tumor immunotherapy by PD-L1 blockade. Proc Natl Acad Sci U S A. 2002;99(19): 12293-7.

42. Liu J, Hamrouni A, Wolowiec D, Coiteux V, Kuliczkowski K, Hetuin D, et al. Plasma cells from multiple myeloma patients express B7-H1 (PD-L1) and increase expression after stimulation with IFN-\{gamma\} and TLR ligands via a MyD88-, TRAF6-, and MEK-dependent pathway. Blood. 2007;110(1):296-304.

43. Topalian SL, Drake CG, Pardoll DM. Immune checkpoint blockade: a common denominator approach to cancer therapy. Cancer Cell. 2015;27(4):450-61.

44. Skoulidis F, Byers LA, Diao L, Papadimitrakopoulou VA, Tong P, Izzo J, et al. Co-occurring genomic alterations define major subsets of KRAS-mutant lung adenocarcinoma with distinct biology, immune profiles, and therapeutic vulnerabilities. Cancer Discov. 2015;5(8):860-77.

45. Chen N, Fang W, Zhan J, Hong S, Tang Y, Kang S, et al. Upregulation of PDL1 by EGFR activation mediates the immune escape in EGFR-driven NSCLC: implication for optional immune targeted therapy for NSCLC patients with EGFR mutation. J Thorac Oncol. 2015;10(6):910-23.

46. Azuma K, Ota K, Kawahara A, Hattori S, Iwama E, Harada T, et al. Association of PD-L1 overexpression with activating EGFR mutations in surgically resected nonsmall-cell lung cancer. Ann Oncol. 2014;25(10):1935-40.

47. Ota K, Azuma K, Kawahara A, Hattori S, Iwama E, Tanizaki J, et al. Induction of PD-L1 expression by the EML4-ALK oncoprotein and downstream signaling pathways in non-small cell lung cancer. Clin Cancer Res. 2015; 21(17):4014-21.

48. Lastwika KJ, Wilson 3rd W, Li QK, Norris J, Xu H, Ghazarian SR, et al. Control of PD-L1 expression by oncogenic activation of the AKT-mTOR pathway in non-small cell lung cancer. Cancer Res. 2016;76(2):227-38.

49. Lou Y, Diao L, Parra Cuentas ER, Denning WL, Chen L, Fan YH, et al. Epithelial-mesenchymal transition is associated with a distinct tumor microenvironment including elevation of inflammatory signals and multiple immune checkpoints in lung adenocarcinoma. Clin Cancer Res. 2016. doi:10.1158/1078-0432.CCR-15-1434.

50. Ribas A. Adaptive immune resistance: how cancer protects from immune attack. Cancer Discov. 2015;5(9):915-9.

51. Spranger S, Koblish HK, Horton B, Scherle PA, Newton R, Gajewski TF. Mechanism of tumor rejection with doublets of CTLA-4, PD-1/PD-L1, or IDO blockade involves restored IL-2 production and proliferation of CD8(+) T cells directly within the tumor microenvironment. J Immunother Cancer. 2014;2:3.

52. Gatalica Z, Snyder C, Maney T, Ghazalpour A, Holterman DA, Xiao N, et al. Programmed cell death 1 (PD-1) and its ligand (PD-L1) in common cancers and their correlation with molecular cancer type. Cancer Epidemiol Biomarkers Prev. 2014;23(12):2965-70.

53. Okiyama N, Katz SI. Programmed cell death 1 (PD-1) regulates the effector function of CD8 T cells via PD-L1 expressed on target keratinocytes. J Autoimmun. 2014;53:1-9.

54. Hino R, Kabashima K, Kato Y, Yagi H, Nakamura M, Honjo T, et al. Tumor cell expression of programmed cell death-1 ligand 1 is a prognostic factor for malignant melanoma. Cancer. 2010;116(7):1757-66.

55. Blackburn SD, Shin H, Haining WN, Zou T, Workman CJ, Polley A, et al. Coregulation of CD8+ T cell exhaustion by multiple inhibitory receptors during chronic viral infection. Nat Immunol. 2009;10(1):29-37.

56. Nishimura H, Nose M, Hiai H, Minato N, Honjo T. Development of lupus-like autoimmune diseases by disruption of the PD-1 gene encoding an ITIM motif-carrying immunoreceptor. Immunity. 1999;11(2):141-51.

57. Nishimura H, Okazaki T, Tanaka Y, Nakatani K, Hara M, Matsumori A, et al. Autoimmune dilated cardiomyopathy in PD-1 receptor-deficient mice. Science. 2001;291(5502):319-22.

58. Curiel TJ, Wei S, Dong $H$, Alvarez $X$, Cheng $P$, Mottram $P$, et al. Blockade of B7-H1 improves myeloid dendritic cell-mediated antitumor immunity. Nat Med. 2003;9(5):562-7.

59. Hirano F, Kaneko K, Tamura H, Dong H, Wang S, Ichikawa M, et al. Blockade of B7-H1 and PD-1 by monoclonal antibodies potentiates cancer therapeutic immunity. Cancer Res. 2005;65(3):1089-96.

60. Curran MA, Montalvo W, Yagita H, Allison JP. PD-1 and CTLA-4 combination blockade expands infiltrating $T$ cells and reduces regulatory $T$ and myeloid cells within B16 melanoma tumors. Proc Natl Acad Sci U S A. 2010;107(9):4275-80.

61. Woo SR, Turnis ME, Goldberg MV, Bankoti J, Selby M, Nirschl CJ, et al. Immune inhibitory molecules LAG-3 and PD-1 synergistically regulate T-cell function to promote tumoral immune escape. Cancer Res. 2012;72(4):917-27.

62. Tsai KK, Daud Al. Nivolumab plus ipilimumab in the treatment of advanced melanoma. J Hematol Oncol. 2015;8(1):123. 
63. Massi D, Brusa D, Merelli B, Ciano M, Audrito V, Serra S, et al. PD-L1 marks a subset of melanomas with a shorter overall survival and distinct genetic and morphological characteristics. Ann Oncol. 2014;25(12):2433-42.

64. Wong RM, Scotland RR, Lau RL, Wang C, Korman AJ, Kast WM, et al, Programmed death-1 blockade enhances expansion and functional capacity of human melanoma antigen-specific CTLs. Int Immunol. 2007;19(10):1223-34.

65. Wang W, Lau R, Yu D, Zhu W, Korman A, Weber J. PD1 blockade reverses the suppression of melanoma antigen-specific CTL by CD4+ CD25(Hi) regulatory T cells. Int Immunol. 2009;21(9):1065-77.

66. Charlton JJ, Chatzidakis I, Tsoukatou D, Boumpas DT, Garinis GA, Mamalaki C. Programmed death-1 shapes memory phenotype CD8 T cell subsets in a cellintrinsic manner. J Immunol. 2013;190(12):6104-14.

67. Topalian SL, Sznol M, McDermott DF, Kluger HM, Carvajal RD, Sharfman WH, et al. Survival, durable tumor remission, and long-term safety in patients with advanced melanoma receiving nivolumab. J Clin Oncol. 2014;32(10):1020-30.

68. MERCK. FDA approves KEYTRUDA ${ }^{\circledR}$ (pembrolizumab) for the treatment of patients with metastatic non-small cell lung cancer whose tumors express PDL1 with disease progression on or after platinum-containing chemotherapy. 2015. http://www.mercknewsroom.com/news-release/prescription-medicinenews/fda-approves-keytruda-pembrolizumab-treatment-patients-metas.

69. Fox BA, Schendel DJ, Butterfield LH, Aamdal S, Allison JP, Ascierto PA, et al. Defining the critical hurdles in cancer immunotherapy. J Transl Med. 2011;9:214.

70. Butterfield LH, Disis ML, Khleif SN, Balwit JM, Marincola FM. Immunooncology biomarkers 2010 and beyond: perspectives from the iSBTC/SITC biomarker task force. J Transl Med. 2010;8:130

71. Bedognetti D, Balwit JM, Wang E, Disis ML, Britten CM, Delogu LG, et al. SITC/ISBTC cancer immunotherapy biomarkers resource document: online resources and useful tools - a compass in the land of biomarker discovery. J Transl Med. 2011;9:155.

72. Yuan J, Hegde PS, Clynes R, Foukas PG, Harari A, Kleen TO, et al. Novel technologies and emerging biomarkers for personalized cancer immunotherapy. J Immunother Cancer. 2016;4:3.

73. Hansen AR, Siu LL. PD-L1 testing in cancer: challenges in companion diagnostic development. JAMA Oncol. 2016;2(1):15-6.

74. Ratcliffe MJ, Sharpe A, Midha A, Barker C, Scorer P, Walker J. A comparative study of PD-L1 diagnostic assays and the classification of patients at PD-L1 positive and PD-L1 negative [abstract]. In: Proceedings of the 107th Annual Meeting of the American Association for Cancer Research; 2016 Apr 16-20. New Orleans, LA Philadelphia (PA): AACR; 2016. Abstract nr LB-094.

75. Gandini S, Massi D, Mandala M. PD-L1 expression in cancer patients receiving anti PD-1/PD-L1 antibodies: a systematic review and meta-analysis. Crit Rev Oncol Hematol. 2016;100:88-98.

76. Leffers N, Gooden MJ, de Jong RA, Hoogeboom BN, ten Hoor KA, Hollema $\mathrm{H}$, et al. Prognostic significance of tumor-infiltrating T-lymphocytes in primary and metastatic lesions of advanced stage ovarian cancer. Cancer Immunol Immunother. 2009;58(3):449-59.

77. Hwang WT, Adams SF, Tahirovic E, Hagemann IS, Coukos G. Prognostic significance of tumor-infiltrating $T$ cells in ovarian cancer: a meta-analysis. Gynecol Oncol. 2012;124(2):192-8.

78. Erdag G, Schaefer JT, Smolkin ME, Deacon DH, Shea SM, Dengel LT, et al. Immunotype and immunohistologic characteristics of tumor-infiltrating immune cells are associated with clinical outcome in metastatic melanoma. Cancer Res. 2012;72(5):1070-80.

79. Feng Z, Puri S, Moudgil T, Wood W, Hoyt CC, Wang C, et al. Multispectral imaging of formalin-fixed tissue predicts ability to generate tumor-infiltrating lymphocytes from melanoma. J Immunother Cancer. 2015;3:47.

80. Stack EC, Wang C, Roman KA, Hoyt CC. Multiplexed immunohistochemistry, imaging, and quantitation: a review, with an assessment of Tyramide signal amplification, multispectral imaging and multiplex analysis. Methods. 2014; 70(1):46-58

81. Ichihara F, Kono K, Takahashi A, Kawaida H, Sugai H, Fujii H. Increased populations of regulatory $T$ cells in peripheral blood and tumor-infiltrating lymphocytes in patients with gastric and esophageal cancers. Clin Cancer Res. 2003;9(12):4404-8

82. Basu S, Campbell HM, Dittel BN, Ray A. Purification of specific cell population by fluorescence activated cell sorting (FACS). J Vis Exp. 2010(41): e1546. doi:10.3791/1546.

83. Zaritskaya L, Shurin MR, Sayers TJ, Malyguine AM. New flow cytometric assays for monitoring cell-mediated cytotoxicity. Expert Rev Vaccines. 2010; $9(6): 601-16$
84. Yuan J, Gnjatic S, Li H, Powel S, Gallardo HF, Ritter E, et al. CTLA-4 blockade enhances polyfunctional NY-ESO-1 specific T cell responses in metastatic melanoma patients with clinical benefit. Proc Natl Acad Sci U S A. 2008; 105(51):20410-5.

85. Attig S, Price $L$, Janetzki $S$, Kalos M, Pride M, McNeil L, et al. A critical assessment for the value of markers to gate-out undesired events in HLApeptide multimer staining protocols. J Transl Med. 2011;9:108.

86. McNeil LK, Price L, Britten CM, Jaimes M, Maecker H, Odunsi K, et al. A harmonized approach to intracellular cytokine staining gating: results from an international multiconsortia proficiency panel conducted by the cancer immunotherapy consortium (CIC/CRI). Cytometry A. 2013;83(8):728-38.

87. Vales-Gomez M, Reyburn HT, Erskine RA, Lopez-Botet M, Strominger JL. Kinetics and peptide dependency of the binding of the inhibitory NK receptor CD94/NKG2-A and the activating receptor CD94/NKG2-C to HLA-E. EMBO J. 1999;18(15):4250-60.

88. Maecker HT, Harari A. Immune monitoring technology primer: flow and mass cytometry. J Immunother Cancer. 2015;3:44.

89. Kerr KM, Tsao MS, Nicholson AG, Yatabe Y, Wistuba II, Hirsch FR, et al. Programmed death-ligand 1 immunohistochemistry in lung cancer: in what state is this art? J Thorac Oncol. 2015;10(7):985-9.

90. Gnjatic S, Ritter E, Buchler MW, Giese NA, Brors B, Frei C, et al. Seromic profiling of ovarian and pancreatic cancer. Proc Natl Acad Sci U S A. 2010; 107(11):5088-93.

91. Yuan J, Wang E, Fox BA. Immune monitoring technology primer: protein microarray ('seromics'). J Immunother Cancer. 2016;4:2.

92. Inc. TFS. General information, technology overview, and applications using the ProtoArray ${ }^{\circledast}$ Human Protein Microarray. ProtoArray ${ }^{\circledast}$ Applications Guide. 2015. https://tools.thermofisher.com/content/sfs/manuals/protoarray_ applicationsguide_man.pdf.

93. Janetzki S, Price L, Schroeder H, Britten CM, Welters MJ, Hoos A. Guidelines for the automated evaluation of Elispot assays. Nat Protoc. 2015;10(7):1098-115.

94. Malyguine AM, Strobl S, Dunham K, Shurin MR, Sayers TJ. ELISPOT assay for monitoring cytotoxic T lymphocytes (CTL) activity in cancer vaccine clinical trials. Cells. 2012;1(2):111-26.

95. Janetzki S, Panageas KS, Ben-Porat L, Boyer J, Britten CM, Clay TM, et al. Results and harmonization guidelines from two large-scale international Elispot proficiency panels conducted by the cancer vaccine consortium (CVC/SVI). Cancer Immunol Immunother. 2008;57(3):303-15.

96. Butterfield LH, Buffo MJ. Immunologic monitoring of cancer vaccine trials using the ELISPOT assay. Methods Mol Biol. 2014;1102:71-82.

97. Gabrielsson S, Brichard V, Dhellin O, Dorval T, Bonnerot C. IFN-gamma responses in peptide-treated melanoma patients measured by an ELISPOT assay using allogeneic dendritic cells. Anticancer Res. 2004;24(1):171-7.

98. Scheibenbogen C, Lee KH, Stevanovic S, Witzens M, Willhauck M, Waldmann $V$, et al. Analysis of the T cell response to tumor and viral peptide antigens by an IFNgamma-ELISPOT assay. Int J Cancer. 1997;71(6):932-6.

99. Janetzki S. Immune monitoring technology primer: the enzyme-linked immunospot (Elispot) and fluorospot assay. J Immunother Cancer. 2015;3:30

100. Robins HS, Ericson NG, Guenthoer J, O'Briant KC, Tewari M, Drescher CW, et al. Digital genomic quantification of tumor-infiltrating lymphocytes. Sci Transl Med. 2013;5(214):214ra169.

101. Cha E, Klinger M, Hou Y, Cummings C, Ribas A, Faham M, et al. Improved survival with $T$ cell clonotype stability after anti-CTLA-4 treatment in cancer patients. Sci Transl Med. 2014;6(238):238ra270.

102. Schumacher TN, Schreiber RD. Neoantigens in cancer immunotherapy. Science. 2015;348(6230):69-74.

103. Gubin MM, Artyomov MN, Mardis ER, Schreiber RD. Tumor neoantigens: building a framework for personalized cancer immunotherapy. J Clin Invest. 2015;125(9):3413-21.

104. Snyder A, Makarov V, Merghoub T, Yuan J, Zaretsky JM, Desrichard A, et al. Genetic basis for clinical response to CTLA-4 blockade in melanoma. N Engl J Med. 2014:371(23):2189-99.

105. Rizvi NA, Hellmann MD, Snyder A, Kvistborg P, Makarov V, Havel JJ, et al. Cancer immunology. Mutational landscape determines sensitivity to PD-1 blockade in non-small cell lung cancer. Science. 2015; 348(6230):124-8.

106. Hugo W, Zaretsky JM, Sun L, Song C, Moreno BH, Hu-Lieskovan S, et al. Genomic and transcriptomic features of response to anti-PD-1 therapy in metastatic melanoma. Cell. 2016;165(1):35-44.

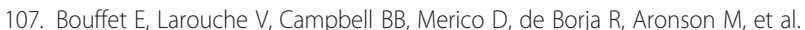
Immune checkpoint inhibition for hypermutant glioblastoma multiforme 
resulting from germline biallelic mismatch repair deficiency. J Clin Oncol. 2016. doi: 10.1200/JCO.2016.66.6552.

108. Hoffmann S, Cepok S, Grummel V, Lehmann-Horn K, Hackermuller J, Stadler PF, et al. HLA-DRB1*0401 and HLA-DRB1*0408 are strongly associated with the development of antibodies against interferon-beta therapy in multiple sclerosis. Am J Hum Genet. 2008:83(2):219-27.

109. International Multiple Sclerosis Genetics C, Wellcome Trust Case Control C, Sawcer S, Hellenthal G, Pirinen M, Spencer CC, et al. Genetic risk and a primary role for cell-mediated immune mechanisms in multiple sclerosis. Nature. 2011;476(7359):214-9.

110. Konishi J, Yamazaki K, Azuma M, Kinoshita I, Dosaka-Akita H, Nishimura M. B7-H1 expression on non-small cell lung cancer cells and its relationship with tumor-infiltrating lymphocytes and their PD-1 expression. Clin Cancer Res. 2004;10(15):5094-100.

111. Chen YY, Wang LB, Zhu HL, Li XY, Zhu YP, Yin YL, et al. Relationship between programmed death-ligand 1 and clinicopathological characteristics in non-small cell lung cancer patients. Chin Med Sci J. 2013; 28(3):147-51.

112. Massi D, Brusa D, Merelli B, Falcone C, Xue G, Carobbio A, et al. The status of PD-L1 and tumor-infiltrating immune cells predict resistance and poor prognosis in BRAFi-treated melanoma patients harboring mutant BRAFV600. Ann Oncol. 2015;26(9):1980-7.

113. Taube JM, Klein A, Brahmer JR, Xu H, Pan X, Kim JH, et al. Association of PD1, PD-1 ligands, and other features of the tumor immune microenvironment with response to anti-PD-1 therapy. Clin Cancer Res. 2014;20(19):5064-74.

114. Le DT, Uram JN, Wang H, Bartlett BR, Kemberling H, Eyring AD, et al. PD-1 blockade in tumors with mismatch-repair deficiency. N Engl J Med. 2015; 372(26):2509-20.

115. Tran E, Ahmadzadeh M, Lu YC, Gros A, Turcotte S, Robbins PF, et al. Immunogenicity of somatic mutations in human gastrointestinal cancers. Science. 2015;350(6266):1387-90.

116. Lin AY, Lin E. Programmed death 1 blockade, an Achilles heel for MMRdeficient tumors? J Hematol Oncol. 2015:8(1):124.

117. Robbins PF, Lu YC, El-Gamil M, Li YF, Gross C, Gartner J, et al. Mining exomic sequencing data to identify mutated antigens recognized by adoptively transferred tumor-reactive T cells. Nat Med. 2013;19(6):747-52.

118. Gros A, Parkhurst MR, Tran E, Pasetto A, Robbins PF, Ilyas S, et al. Prospective identification of neoantigen-specific lymphocytes in the peripheral blood of melanoma patients. Nat Med. 2016;22(4):433-8.

119. Velcheti V, Schalper KA, Carvajal DE, Anagnostou VK, Syrigos KN, Sznol M, et al. Programmed death ligand-1 expression in non-small cell lung cancer. Lab Invest. 2014;94(1):107-16.

120. Ahmadzadeh M, Johnson LA, Heemskerk B, Wunderlich JR, Dudley ME, White DE, et al. Tumor antigen-specific CD8 T cells infiltrating the tumor express high levels of PD-1 and are functionally impaired. Blood. 2009;114(8):1537-44.

121. Tumeh PC, Harview CL, Yearley JH, Shintaku IP, Taylor EJ, Robert L, et al. PD1 blockade induces responses by inhibiting adaptive immune resistance. Nature. 2014;515(7528):568-71.

122. Yung S, Ledran M, Moreno-Gimeno I, Conesa A, Montaner D, Dopazo J, et al. Large-scale transcriptional profiling and functional assays reveal important roles for Rho-GTPase signalling and SCL during haematopoietic differentiation of human embryonic stem cells. Hum Mol Genet. 2011; 20(24):4932-46.

123. Galon J, Mlecnik B, Bindea G, Angell HK, Berger A, Lagorce C, et al. Towards the introduction of the 'Immunoscore' in the classification of malignant tumours. J Pathol. 2014;232(2):199-209.

124. Shay T, Jojic V, Zuk O, Rothamel K, Puyraimond-Zemmour D, Feng T, et al. Conservation and divergence in the transcriptional programs of the human and mouse immune systems. Proc Natl Acad Sci U S A. 2013;110(8):2946-51.

125. Brahmer J, Reckamp KL, Baas P, Crino L, Eberhardt WE, Poddubskaya E, et al. Nivolumab versus docetaxel in advanced squamous-cell non-small-cell lung cancer. N Engl J Med. 2015;373(2):123-35.

126. Borghaei H, Paz-Ares L, Horn L, Spigel DR, Steins M, Ready NE, et al. Nivolumab versus docetaxel in advanced nonsquamous non-small-cell lung cancer. N Engl J Med. 2015;373(17):1627-39.

127. Motzer RJ, Escudier B, McDermott DF, George S, Hammers HJ, Srinivas S, et al. Nivolumab versus everolimus in advanced renal-cell carcinoma. N Engl J Med. 2015;373(19):1803-13.

128. Weber JS, D'Angelo SP, Minor D, Hodi FS, Gutzmer R, Neyns B, et al. Nivolumab versus chemotherapy in patients with advanced melanoma who progressed after anti-CTLA-4 treatment (CheckMate 037): a randomised, controlled, open-label, phase 3 trial. Lancet Oncol. 2015;16(4):375-84.

129. Robert C, Long GV, Brady B, Dutriaux C, Maio M, Mortier L, et al. Nivolumab in previously untreated melanoma without BRAF mutation. N Engl J Med. 2015;372(4):320-30.

130. Larkin J, Chiarion-Sileni V, Gonzalez R, Grob JJ, Cowey CL, Lao CD, et al. Combined nivolumab and ipilimumab or monotherapy in untreated melanoma. N Engl J Med. 2015;373(1):23-34.

131. Rizvi NA, Mazieres J, Planchard D, Stinchcombe TE, Dy GK, Antonia SJ, et al. Activity and safety of nivolumab, an anti-PD-1 immune checkpoint inhibitor, for patients with advanced, refractory squamous non-small-cell lung cancer (CheckMate 063): a phase 2, single-arm trial. Lancet Oncol. 2015;16(3):257-65.

132. McDermott DF, Drake CG, Sznol M, Choueiri TK, Powderly JD, Smith DC, et al. Survival, durable response, and long-term safety in patients with previously treated advanced renal cell carcinoma receiving nivolumab. J Clin Oncol. 2015;33(18):2013-20.

133. Gettinger SN, Horn L, Gandhi L, Spigel DR, Antonia SJ, Rizvi NA, et al. Overall survival and long-term safety of nivolumab (anti-programmed death 1 antibody, BMS-936558, ONO-4538) in patients with previously treated advanced non-small-cell lung cancer. J Clin Oncol. 2015;33(18):2004-12.

134. Robert C, Schachter J, Long GV, Arance A, Grob JJ, Mortier L, et al. Pembrolizumab versus ipilimumab in advanced melanoma. N Engl J Med. 2015;372(26):2521-32.

135. Ribas A, Puzanov I, Dummer R, Schadendorf D, Hamid O, Robert C, et al. Pembrolizumab versus investigator-choice chemotherapy for ipilimumabrefractory melanoma (KEYNOTE-002): a randomised, controlled, phase 2 trial. Lancet Oncol. 2015;16(8):908-18.

136. Daud A, Ribas A, Robert C, Hodi FS, Wolchok JD, Joshua AM, et al. Longterm efficacy of pembrolizumab (pembro; MK-3475) in a pooled analysis of 655 patients (pts) with advanced melanoma (MEL) enrolled in KEYNOTE-001. ASCO Meeting Abstr. 2015;33(15_suppl):9005.

137. Ribas A, Hamid O, Daud A, Hodi FS, Wolchok JD, Kefford R, et al. Association of pembrolizumab with tumor response and survival among patients with advanced melanoma. JAMA. 2016;315(15):1600-9.

138. Robert C, Ribas A, Wolchok JD, Hodi FS, Hamid O, Kefford R, et al. Antiprogrammed-death-receptor-1 treatment with pembrolizumab in ipilimumab-refractory advanced melanoma: a randomised dose-comparison cohort of a phase 1 trial. Lancet. 2014;384(9948):1109-17.

139. Nanda R, Chow LQ, Dees EC, Berger R, Gupta S, Geva R, et al. Abstract S1-09: a phase lb study of pembrolizumab (MK-3475) in patients with advanced triplenegative breast cancer. Cancer Res. 2015;75(9 Supplement):S1-09.

140. Herbst RS, Baas P, Kim DW, Felip E, Perez-Gracia JL, Han JY, et al. Pembrolizumab versus docetaxel for previously treated, PD-L1-positive, advanced non-small-cell lung cancer (KEYNOTE-010): a randomised controlled trial. Lancet. 2015:387(10027):1540-50.

141. Moskowitz C, Ribrag V, Michot J-M, Martinelli G, Zinzani PL, Gutierrez M, et al. PD-1 Blockade with the monoclonal antibody Pembrolizumab (M3475) in patients with classical Hodgkin Lymphoma after Brentuximab Vedotin Failure: Preliminary results from a phase 1b study [abstract]. Blood. 2014;124:290. abstract.

142. Spigel DR, Chaft JE, Gettinger SN, Chao BH, Dirix LY, Schmid P, et al. Clinical activity and safety from a phase II study (FIR) of MPDL3280A (anti-PDL1) in PD-L1-selected patients with non-small cell lung cancer (NSCLC). ASCO Meeting Abstr. 2015;33(15_suppl):8028.

143. Spira Al, Park K, Mazieres J, Vansteenkiste JF, Rittmeyer A, Ballinger M, et al. Efficacy, safety and predictive biomarker results from a randomized phase $\|$ study comparing MPDL3280A vs docetaxel in 2L/3L NSCLC (POPLAR). ASCO Meeting Abstr. 2015;33(15_suppl):8010.

144. Hamid O, Sosman JA, Lawrence DP, Sullivan RJ, Ibrahim N, Kluger HM, et al. Clinical activity, safety, and biomarkers of MPDL3280A, an engineered PD-L1 antibody in patients with locally advanced or metastatic melanoma (mM). ASCO Meeting Abstr. 2013;31(15_suppl):9010.

145. Herbst RS, Soria JC, Kowanetz M, Fine GD, Hamid O, Gordon MS, et al. Predictive correlates of response to the anti-PD-L1 antibody MPDL3280A in cancer patients. Nature. 2014;515(7528):563-7.

146. Liu SV, Powderly JD, Camidge DR, Ready N, Heist RS, Hodi FS, et al. Safety and efficacy of MPDL3280A (anti-PDL1) in combination with platinumbased doublet chemotherapy in patients with advanced non-small cell lung cancer (NSCLC). ASCO Meeting Abstr. 2015;33(15_suppl):8030.

147. Bendell JC, Powderly JD, Lieu CH, Eckhardt SG, Hurwitz H, Hochster HS, et al. Safety and efficacy of MPDL3280A (anti-PDL1) in combination with 
bevacizumab (bev) and/or FOLFOX in patients (pts) with metastatic colorectal cancer (mCRC). ASCO Meeting Abstr. 2015;33(3_suppl):704.

148. Sznol M, McDermott DF, Jones SF, Mier JW, Waterkamp D, Rossi C, et al. Phase Ib evaluation of MPDL3280A (anti-PDL1) in combination with bevacizumab (bev) in patients (pts) with metastatic renal cell carcinoma (mRCC). ASCO Meeting Abstr. 2015;33(7_suppl):410.

149. Rizvi NA, Brahmer JR, Ou S-HI, Segal NH, Khleif S, Hwu W-J, et al. Safety and clinical activity of MEDI4736, an anti-programmed cell death-ligand 1 (PDL1) antibody, in patients with non-small cell lung cancer (NSCLC). ASCO Meeting Abstr. 2015;33(15_suppl):8032.

150. Brahmer JR, Rizvi NA, Lutzky J, Khleif S, Blake-Haskins A, Li X, et al. Clinical activity and biomarkers of MEDI4736, an anti-PD-L1 antibody, in patients with NSCLC. ASCO Meeting Abstr. 2014;32(15_suppl):8021.

151. Segal NH, Ou S-HI, Balmanoukian AS, Fury MG, Massarelli E, Brahmer JR, et al. Safety and efficacy of MEDI4736, an anti-PD-L1 antibody, in patients from a squamous cell carcinoma of the head and neck (SCCHN) expansion cohort. ASCO Meeting Abstr. 2015;33(15_suppl):3011.

152. Lutzky J, Antonia SJ, Blake-Haskins A, Li X, Robbins PB, Shalabi AM, et al. A phase 1 study of MEDI4736, an anti-PD-L1 antibody, in patients with advanced solid tumors. ASCO Meeting Abstr. 2014;32(15_suppl):3001.

153. Creelan BC, Chow LQ, Kim D-W, Kim S-W, Yeh T, Karakunnel JJ, et al. Safety and tolerability results from a phase I study of MEDI4736, a human IgG1 anti-programmed cell death-ligand-1 (PD-L1) antibody, combined with gefitinib in patients (pts) with non-small-cell lung cancer (NSCLC). ASCO Meeting Abstr. 2015;33(15_suppl):3047.

154. Antonia SJ, Goldberg SB, Balmanoukian AS, Sanborn RE, Steele K, Narwal R, et al. Phase lb study of MEDI4736, a programmed cell death ligand-1 (PDL1) antibody, in combination with tremelimumab, a cytotoxic Tlymphocyte-associated protein-4 (CTLA-4) antibody, in patients (pts) with advanced NSCLC. ASCO Meeting Abstr. 2015;33(15_suppl):3014.

155. Antonia S, Goldberg SB, Balmanoukian A, Chaft JE, Sanborn RE, Gupta A, et al. Safety and antitumour activity of durvalumab plus tremelimumab in non-small cell lung cancer: a multicentre, phase 1b study. Lancet Oncol. 2016;17(3):299-308.

156. Paz-Ares L, Horn L, Borghaei H, Spigel DR, Steins M, Ready N, et al. Phase III, randomized trial (CheckMate 057 ) of nivolumab (NIVO) versus docetaxel (DOC) in advanced non-squamous cell (non-SQ) non-small cell lung cancer (NSCLC). ASCO Meeting Abstr. 2015;33(18_suppl):LBA109.

157. Gettinger SN, Hellmann MD, Shepherd FA, Antonia SJ, Brahmer JR, Chow LQM, et al. First-line monotherapy with nivolumab (NIVO; anti-programmed death-1 [PD-1]) in advanced non-small cell lung cancer (NSCLC): safety, efficacy and correlation of outcomes with PD-1 ligand (PD-L1) expression. ASCO Meeting Abstr. 2015;33(15_suppl):8025.

158. Antonia SJ, Gettinger SN, Chow LQM, Juergens RA, Borghaei $H$, Shen $Y$, et al. Nivolumab (anti-PD-1; BMS-936558, ONO-4538) and ipilimumab in first-line NSCLC: interim phase I results. ASCO Meeting Abstr. 2014;32(15_suppl):8023.

159. Rizvi NA, Garon EB, Leighl N, Hellmann MD, Patnaik A, Gandhi L, et al. Optimizing PD-L1 as a biomarker of response with pembrolizumab (pembro; MK-3475) as first-line therapy for PD-L1-positive metastatic non-small cell lung cancer (NSCLC): Updated data from KEYNOTE-001. ASCO Meeting Abstr. 2015; 33(15_suppl):8026.

160. Garon EB, Gandhi L, Rizvi N, Hui R, Balmanoukian AS, Patnaik A, et al. Antitumor activity of pembrolizumab (pembro; mk-3475) and correlation with programmed death ligand 1 (pd-11) expression in a pooled analysis of patients (pts) with advanced non-small cell lung carcinoma (NSCLC). Ann Oncol. 2014;25 suppl 4:LBA43.

161. Garon EB, Leighl NB, Rizvi NA, Blumenschein GR, Balmanoukian AS, Eder JP, et al. Safety and clinical activity of MK-3475 in previously treated patients (pts) with non-small cell lung cancer (NSCLC). ASCO Meeting Abstr. 2014; 32(15_suppl):8020.

162. Horn L, Spigel DR, Gettinger SN, Antonia SJ, Gordon MS, Herbst RS, et al. Clinical activity, safety and predictive biomarkers of the engineered antibody MPDL3280A (anti-PDL1) in non-small cell lung cancer (NSCLC): update from a phase la study. ASCO Meeting Abstr. 2015;33(15_suppl):8029.

163. Segal NH, Antonia SJ, Brahmer JR, Maio M, Blake-Haskins A, Li X, et al. Preliminary data from a multi-arm expansion study of MEDI4736, an antiPD-L1 antibody. ASCO Meeting Abstr. 2014;32(15_suppl):3002.

164. Loughlin PM, Cooke TG, George WD, Gray AJ, Stott DI, Going JJ. Quantifying tumour-infiltrating lymphocyte subsets: a practical immuno-histochemical method. J Immunol Methods. 2007;321(1-2):32-40.
165. Carvajal-Hausdorf DE, Schalper KA, Neumeister VM, Rimm DL. Quantitative measurement of cancer tissue biomarkers in the lab and in the clinic. Lab Invest. 2015;95(4):385-96.

166. Chen $\mathrm{KH}$, Yuan $\mathrm{CT}$, Tseng LH, Shun $\mathrm{CT}$, Yeh KH. Case report: mismatch repair proficiency and microsatellite stability in gastric cancer may not predict programmed death-1 blockade resistance. J Hematol Oncol. 2016;9(1):29.

167. Shafer-Weaver K, Rosenberg S, Strobl S, Gregory Alvord W, Baseler M, Malyguine A. Application of the granzyme B ELISPOT assay for monitoring cancer vaccine trials. J Immunother. 2006;29(3):328-35.

168. Barrera L, Rodriguez OA, Morales-Flores R, Garcia-Vicente A, Servín EM, Salinas-Parra F, et al. MINI 02.03 over expression of CD47, decrease of apoptosis and phagocytosis of neutrophils in advanced non-small cell lung cancer patients. J Thoracic Oncol. 2015;10(9_suppl 2):S266.

169. Streitz M, Miloud T, Kapinsky M, Reed MR, Magari R, Geissler EK, et al. Standardization of whole blood immune phenotype monitoring for clinical trials: panels and methods from the ONE study. Transplant Res. 2013;2(1):17.

170. van Dongen JJ, Lhermitte L, Bottcher S, Almeida J, van der Velden VH, FloresMontero J, et al. EuroFlow antibody panels for standardized n-dimensional flow cytometric immunophenotyping of normal, reactive and malignant leukocytes. Leukemia. 2012;26(9):1908-75.

171. Zhao S, Fung-Leung WP, Bittner A, Ngo K, Liu X. Comparison of RNA-Seq and microarray in transcriptome profiling of activated T cells. PLoS One. 2014;9(1):e78644.

172. Kammula US, Serrano OK. Use of high throughput qPCR screening to rapidly clone low frequency tumour specific T-cells from peripheral blood for adoptive immunotherapy. J Transl Med. 2008:6:60.

173. Lin SH, He J, Edelman M, Xu T, Gao H, Reuben J, et al. MINI 02.04 sequential assessment of DNA damage response and PD-L1 expression in circulating cells of lung cancer patients during treatment with radiotherapy. J Thoracic Oncol. 2015;10(9_suppl 2):S266-7.

174. Adams DL, Martin SS, Alpaugh RK, Charpentier M, Tsai S, Bergan RC, et al. Circulating giant macrophages as a potential biomarker of solid tumors. Proc Natl Acad Sci U S A. 2014:111(9):3514-9.

\section{Submit your next manuscript to BioMed Central and we will help you at every step:}

- We accept pre-submission inquiries

- Our selector tool helps you to find the most relevant journal

- We provide round the clock customer support

- Convenient online submission

- Thorough peer review

- Inclusion in PubMed and all major indexing services

- Maximum visibility for your research

Submit your manuscript at www.biomedcentral.com/submit
C Biomed Central 